\title{
An analysis of the floristic composition and diversity of Amazonian forests including those of the Guiana Shield
}

\author{
HANS TER STEEGE ${ }^{* \dagger}$, DANIEL SABATIER ${ }^{\ddagger}$ HERNAN CASTELLANOS ${ }^{\S}$, \\ TINDE VAN ANDEL ${ }^{* \dagger}$, JOOST DUIVENVOORDEN*, ALEXANDRE \\ ADALARDO DE OLIVEIRA ${ }^{\pi}$, RENSKE EK ${ }^{* \dagger}$, RAMESH LILWAH ${ }^{+* *}$, PAUL \\ MAAS $^{*}$ and SCOTT MORI ${ }^{\dagger \dagger}$
}

*Department of Plant Ecology, Utrecht University, PO Box 80084, 3504 TB Utrecht, The Netherlands (h.tersteege@bio.uu.nl)

${ }^{\dagger}$ The Tropenbos Guyana Programme, 12E Garnett Street, Campbellville, Georgetown, Guyana

${ }^{\ddagger}$ ORSTOM, Laboratoire Botanique, 163 Rue A. Broussonet, 34000 Montpellier, France

${ }^{\S}$ Universidad Nacional Experimental de Guayana, Calle Chile, Urbaniz Chilemex, Puerto Ordaz, Edo. Bolivar, Venezuela

${ }^{\#} H u g o$ de Vries laboratory, University of Amsterdam, Kruislaan 318, 1098 SM Amsterdam, The Netherlands

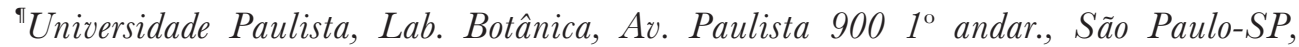
01310-100, Brazil

${ }^{* * *}$ National Agricultural Research Institute, Mon Repos, ECD, Guyana

${ }^{\dagger}$ Institute of Systematic Botany, The New York Botanical Garden, Bronx, New York 10458-5126 USA

(Accepted 9th April 2000)

\begin{abstract}
A large number of newly published and unpublished hectare plots in Amazonia and the Guiana Shield area allow an analysis of family composition and testing of hypotheses concerning alpha-diversity in the south American rain forest. Using data from 94 plots the family-level floristic patterns in wet tropical South America are described. To test diversity patterns, 268 plots are used in this large area. Contrary to a widely held belief, western Amazonian plots are not necessarily the most diverse. Several central Amazonian plots have equal or even higher tree diversity. Annual rainfall is not a good estimator for tree diversity in the Amazonia area and Guiana shield. Plots in the Guiana Shield area (and eastern Amazonia) usually have lower diversity than those in central or western Amazonia. It is argued that this is not because of low rainfall or low nutrient status of the soil but because of the small area of the relatively isolated rain forest area in eastern Amazonia and the Guiana Shield. The low diversity on nutrient-poor white sand soils in the
\end{abstract}


Amazon basin is not necessarily due to their low nutrient status but is, at least partly, caused by their small extent and fragmented nature.

KEY WORDS: Amazonia, floristic composition, Guiana Shield, rainfall, tree alpha diversity

\section{INTRODUGTION}

Neotropical rain forests have been considered the most species-rich forests that exist worldwide (Gentry 1988a, 1988b; Valencia et al. 1994). Very high alpha-diversities of trees, birds, butterflies, reptiles, amphibians and mammals (Gentry 1988a, and references therein) suggest that in particular western Amazonia has an almost unrivalled species diversity. Forests in the east of Amazonia and especially the Guianas are characterized by lower diversity when compared to western Amazonia, both in plants (ter Steege 1998a) and mammals (Kay et al. 1997, Voss \& Emmons 1996). In terms of plant families, Bombacaceae, Meliaceae and Moraceae are richer in species in western Amazonia while Chrysobalanaceae and Lecythidaceae are relatively richer in species in the eastern Amazonia and the Guianas (Gentry 1990, Ek \& ter Steege 1998). However, while some general patterns have been described, a comparison of tree species composition and tree diversity between Amazonia and the Guiana Shield has never been attempted. Below we briefly summarize the state of knowledge at present.

\section{Floristic patterns}

A first attempt to classify the forest types of Amazonia was made by Ducke \& Black (1954). Later classifications were by, for example, Pires \& Prance (1984) and Prance (1987). The classification of forests was based on climate, soil and physiognomy, with some account of species composition. A very thorough forest inventory has been carried out in Brazilian Amazonia (Radambrasil 1968-1978, SUDAM 1974) but the data of these inventories have never become available in the literature (Rollet 1993). Thus, numerical comparisons over large areas remain scarce. In a recent publication in this journal Terborgh \& Andresen (1998) produced an excellent first analysis of large-scale patterns in Amazonia, focusing on 'family-composition' gradients. Unfortunately, this analysis relied heavily on plots in western Amazonia. Data from the Guiana Shield and also from central Amazonia were scarce. Terborgh \& Andresen (1998) concluded that plots forming the outliers in the ordination were dominated by minor plant families (e.g. plots in Guyana by Chrysobalanaceae and a plot near Sao Paulo by Euphorbiaceae). However, plots on the edge of an ordination are not necessarily 'outliers', and Chrysobalanaceae and Euphorbiaceae are not exactly minor plant families with 400 and 2500 species in the neotropics respectively (Maas \& Westra 1993). 


\section{Diversity patterns}

Until now most studies examining the patterns of plant diversity in the neotropics have also relied heavily on plots in western Amazonia (Clinebell et al. 1995, Gentry 1988a,b; Givnish 1999, Phillips et al. 1994). In western Amazonia, species richness is strongly correlated with total annual rainfall (Gentry 1988a,b), which is often considered a proximate estimate of ecosystem productivity (Clinebell et al. 1995, Gentry 1988a, b; Phillips et al. 1994). Rainfall shows a stronger correlation with species richness than do soil fertility and soil toxicity factors (Clinebell et al. 1995). Givnish (1999) argued that by favouring natural enemies of plants (fungi and insects), higher rainfall would promote more density dependent mortality and hence higher diversity. Other studies have confirmed the rainfall-diversity correlation (Hall 1980, 1994; Huston \& Swaine 1976). In each of these studies fertility was negatively correlated with rainfall, complicating the search for single causal relationships. But the signals are also confusing. Phillips et al. (1994) did not find a strong link between rainfall and diversity, allegedly, because they did not include the climatic extremes (Clinebell et al. 1995). Because probably $90 \%$ of the neotropical rain forests do not occur near 'climatic extremes', it appears that the model, as proposed by Clinebell et al. (1995), in which annual rainfall and periodicity are the most important factors, may not be sufficient in predicting species diversity over major areas of Amazonia (as will be further shown below).

Habitat diversity contributes significantly to regional species diversity. Species may differentiate along topographical differences and soil types (Guianas: e.g. Sabatier et al. 1997, Schulz 1960, ter Steege et al. 1993, ter Steege 1998a; W. Amazonia: e.g. Duivenvoorden \& Lips 1995, 1998; Tuomisto \& Ruokolainen 1997, Tuomisto et al. 1995).

Historical events are also considered to have had a large influence on diversity. As an example, Pleistocene fluctuations may have led to contracting and expanding rain forests and through isolation of tree populations have contributed to speciation (Prance 1982, for recent reviews see Bush 1994, Haffer 1997). However, such hypotheses are notoriously difficult to test and often lead to circular reasoning (Tuomisto \& Ruokolainen 1997) and in fact may have been based on collector artefacts (Nelson et al. 1990). Other evidence suggests that many of the present-day species may have evolved before the Pleistocene climate changes (see examples in Bush 1994, Kay et al. 1997).

\section{The Guiana Shield}

The number of floristic plots in the Guiana Shield area has risen steadily over the years and, combined with the relatively well-known flora, this has led to high quality data (Comiskey et al. 1994, Ek 1997, Johnston \& Gillman 1995, Maas 1971, Sabatier 1990, D. Sabatier \& M.F. Prévost, unpubl. data, T. van Andel, unpubl. data). The forest is generally species-poor (ter Steege 1998a) over the full rainfall range $\left(2000-5000 \mathrm{~mm} \mathrm{y}^{-1}\right)$. Including these plots of 
species-poor forests, and several new plots from central and eastern Amazonia, occurring under rainfall regimes similar to the older studies in an analysis of species composition and diversity may greatly increase our understanding of causes of diversity in the Amazon.

In the present paper we examine whether the rainfall-diversity hypothesis is capable of explaining woody species diversity in a dataset that includes the forests of the Guiana Shield and eastern Amazonia. We also present an analysis of family-level floristic composition, comparing the Guianan forest block with that of central and western Amazonia. From the large-scale patterns some smallerscale patterns follow. To carry out these analyses we lent heavily on previously published material but many plots are from previously unpublished data.

\section{METHODS}

Our analysis focuses on family-level floristic composition and diversity of 268 forest plots that are well distributed over Amazonia and the adjacent Guiana Shield (Figures 1, 3). However, the same information was not available for all

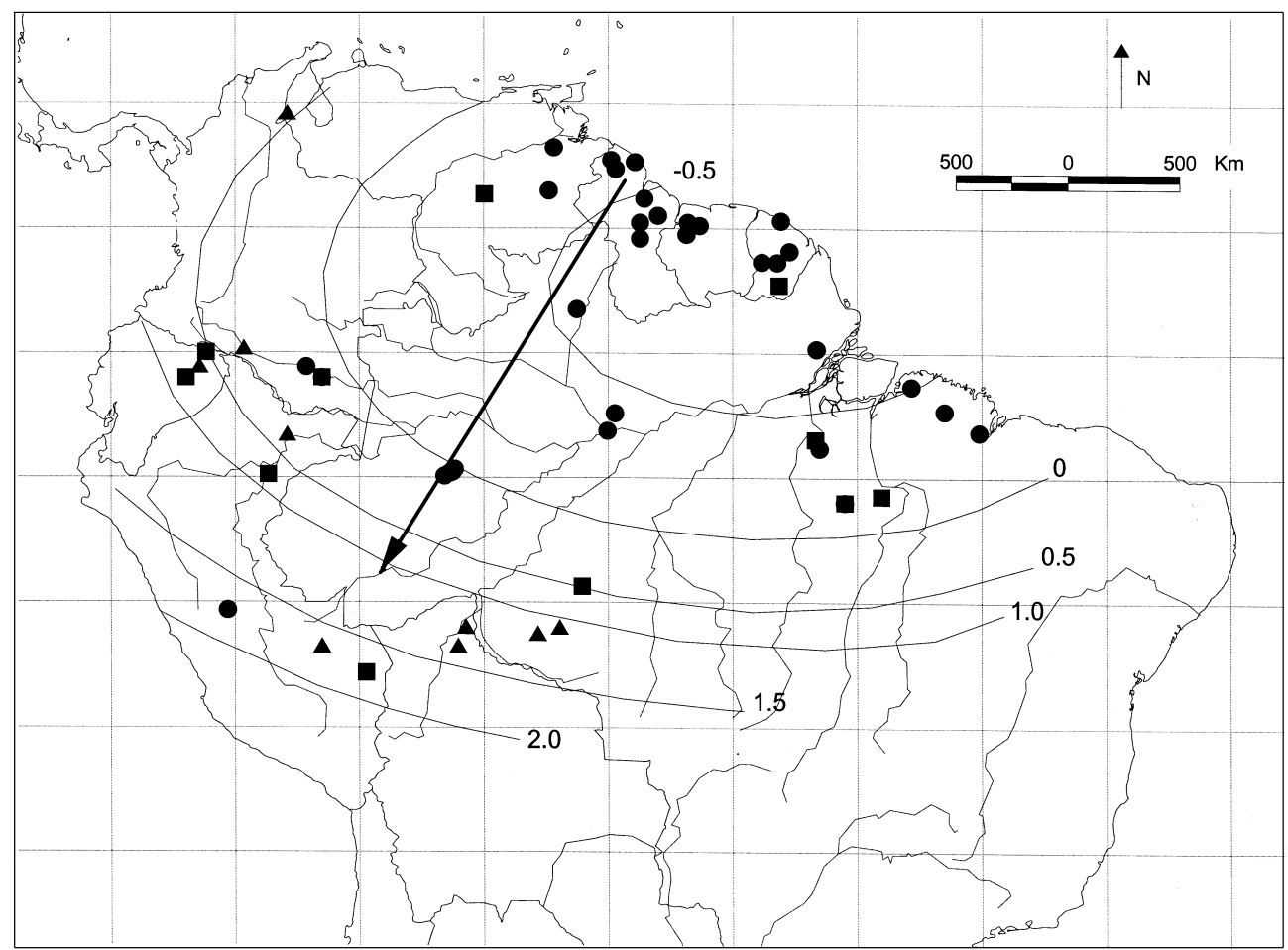

Figure 1. Locations and plot scores of 70 Amazonian terra firme (TF) plots used in a multidimensional scaling ordination based on the abundance of the 16 most dominant tree families. Scores are indicated in three classes: $<0$, $\boldsymbol{\square}$ between $0-1, \boldsymbol{\Delta}>1$. The elliptic lines are isoclines of a spatial quadratic regression (see text) on MDS plot scores. The arrow from Guyana to Peru indicates the direction of a linear spatial regression (see text) and the major direction of the spatial gradient described. 


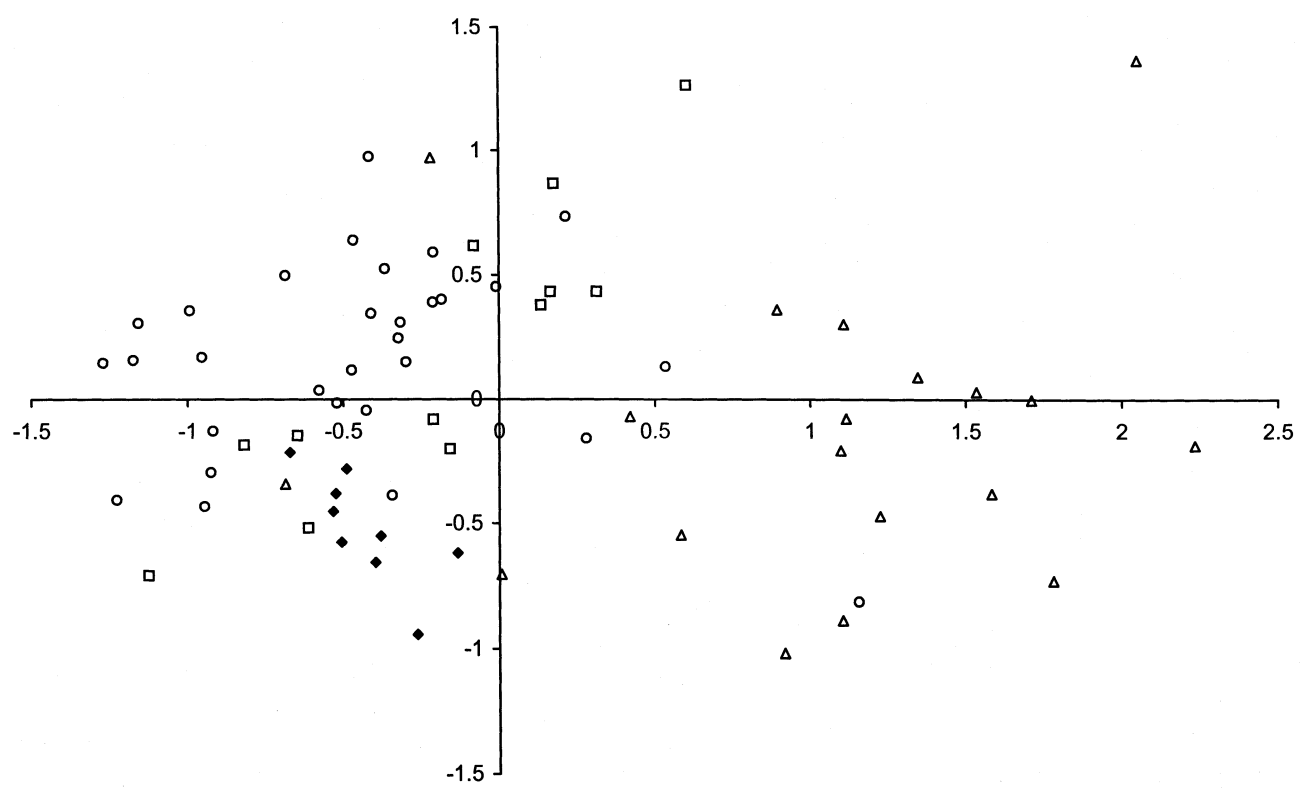

Figure 2. Ordination by multidimensional scaling of 70 Amazonian terra firme (TF) plots on the basis of their similarity in numbers of individuals in 16 major plant families. Similarity was calculated with correlation coefficients. Symbols: $\diamond$, central Amazonia, $\square$, eastern Amazonia; $\bigcirc$, Guiana Shield; $\triangle$, western Amazonia and Rondônia.

plots thus the floristic analyses and diversity analyses were carried out on different subsets of the data.

\section{Floristic composition}

Less than half of the plots have floristic information in the form of the number of individuals by species or only by family. To avoid over-representation of certain sites, the number of plots per forest type (TF, terra firme; FL, floodplain; PZ, podzol; SW, swamp; DF, dry forest) was reduced to two per site. In this case we selected the site with the lowest diversity (highest dominance) and the highest diversity (lowest dominance). While strictly speaking this may be considered pseudo-replication, plots closer to each will in principle be more similar to each other due to spatial auto-correlation (and they should also be closer on a gradient when ordinated). We tested for spatial auto-correlation with Variowin 2.21 (Pannatier 1996) and with Spatialstats (S-PLUS 2000, Mathsoft Inc.).

For floristic analysis 105 plots were available (Appendix 1). Our first set of 48 plots was derived from Table 2 of Terborgh \& Andresen (1998). We could duplicate the main results of Terborgh \& Andresen (1998) by using the 16 most abundant families reported in their Table 2. The 16 families were Annonaceae, Arecaceae, Bombacaceae, Burseraceae, Chrysobalanaceae, Euphorbiaceae, Lauraceae, Lecythidaceae, Leguminosae, Meliaceae, Moraceae, Myristicaceae, Rubiaceae, Sapotaceae, Sterculiaceae and Violaceae. We concluded that these 




Figure 3. Location of Amazonian terra firme (TF) plots used in the analysis of tree alpha-diversity. Dot size indicates the value of Fisher's alpha (in case of overlap only the highest may be visible). Grey-scales indicate interpolated values of Fisher's alpha (with interdistance weighting up to $500 \mathrm{~km}$ ).

abundantly present families, which amounted to $65-96 \%$ of all individuals on the plots (Terborgh \& Andresen 1998) dominated the analysis, and, not unimportantly, neotropical rain forests.

To make the other plots comparable to the first set we used the same criteria as Terborgh \& Andresen (1998): a plot size of $\geqslant 1$ ha and only trees with DBH $\geqslant 10 \mathrm{~cm}$ were used. Such plots capture a fair amount of the local diversity (Laurance et al. 1998, but see Condit et al. 1998). The plots were truncated to 450 trees by randomly selecting 450 individuals and assigning these to their respective families (note that only the 16 families mentioned were used for the ordinations below). We made a few exceptions to include plots of areas where no other data were available:

(i) Three plots with fewer individuals: San Pedro, Venezuela, 443 individuals (Finol Urdaneto undated); Haut Camopi, French Guiana, 435 individuals (Sabatier \& Prevost 1987); and Jaru, Rondônia, 442 individuals (Absy et al. 1987).

(ii) In the case of Saimadodyi, Venezuela (Lizarralde 1997) and El Tigre, Bolivia (Bergmans \& Vroomans 1995) only average numbers per family were available for combined plots. Here we calculated the number of individuals per family not by random selection but by converting the percentage of individuals to numbers within a sample of 450 trees. 
(iii) Two plots were based on plotless tree samples along a line (within one forest type) rather than on a 1-ha plot basis (Mori \& Boom 1987, Mori et al. 1989). In this case the first 450 trees sampled were used.

Species and genus information was not used in the analysis. This is an obvious drawback as evolution and competition take place at this level rather than at the family level. However, as Terborgh \& Andresen (1998) pointed out, the data at species and genus level contains too much noise to produce interpretable results.

We recognized four main 'forest types': forests on ultisols and oxisols, so called 'terra firme' forest (TF); forests on floodplains (FL); forests on white sand podzols or spodosols (PZ); and swamp forests (SW). Initially, the plots were assigned to eight regions: western Amazonia (WA), Rondônia (RO), central Amazonia (CA), eastern Amazonia (EA), Guiana Shield (GS), Chocó, Central America, Atlantic Brazil.

Swamp plots $(\mathrm{n}=2)$ were not included in the multivariate floristic analyses (see Terborgh \& Andresen 1998). Because the floras from the Chocó area, Central America and the Atlantic forest are relatively separated geographically from the main large Amazonian forest mass and because we had only a few plots in them, we also omitted the plots from these areas from the final analysis. The Rondônia plots resembled western Amazonian plots most closely, and because of their geographical proximity, were added to WA.

The remaining data (94 plots) were analysed with principal component analysis and detrended correspondence analysis (MVSP 3.01, Kovach Computing Services) on the basis of the 16 major plant families. We also compared the results of these ordinations with multidimensional scaling (with both a correlation matrix and Euclidean distance matrix as input, Statistica 4.5, Statsoft, Inc.) and chose the ordination that best separated the data spatially.

We also analysed the data of the TF plots $(\mathrm{n}=70)$ and FL plots $(\mathrm{n}=24)$ separately.

\section{Diversity patterns}

Almost all plots $(\mathrm{n}=258)$ have information on the number of individuals and number of species, which were used for the calculation of alpha-diversity (Appendix 1, Figure 3). Many of these plots were gathered from the literature but again a substantial portion of these plots comes from our own work.

Alpha-diversity was quantified with Fisher's alpha (Fisher et al. 1943, Rosenzweig 1995, Taylor et al. 1976) using all individuals and species per plot. Fisher's alpha, which is relatively insensitive to sample size, performs very well on data of forest plots (Condit et al. 1998, Leigh 1995). Using all plots for the calculation of alpha-diversity allows us to compare local differences of diversity with regional differences. Core Amazonian rain forest plots were defined as those occurring east of the Andes, between $8^{\circ} \mathrm{S}$ to $8^{\circ} \mathrm{N}$, with rainfall $\geqslant 2000$ $\mathrm{mm}$. This set includes the hyper-diverse plots of Peru and Ecuador but excludes 
the dry (deciduous) forest plots in Venezuela and Bolivia. Differences between regions and forests were analysed with ANOVA, post-hoc comparisons were carried out with Scheffé's tests. We tested for spatial auto-correlation with Variowin 2.21 (Pannatier 1996) and Spatialstats (S-PLUS 2000, Mathsoft Inc.).

\section{Productivity}

For just a few sites in the neotropics net primary productivity has been estimated on the basis of field measurements-San Carlos de Rio Negro and Reserva Ducke (Raich et al. 1991). We use one proxy estimate for productivity, rainfall (e.g. Clinebell et al. 1995, Gentry 1988a, b; Phillips et al. 1994), which shows good correlation with modelled net primary productivity (Raich et al. 1991). We analysed the relationship between alpha-diversity and rainfall for the complete data set (including low rainfall plots) and various subsets, based on region, edaphic condition and major soil type with regression analysis.

Maps were created with Arcview 3.1 (ESRI Inc.).

\section{RESULTS}

\section{Floristic patterns}

The 16 families considered in the analyses made up 79\% of the tree populations in the Amazonia, if we assume the plots to be representative for the area. Leguminosae dominate the neotropical forests. On average 16\% of all individuals on the plots were Leguminosae (Table 1).

In half of the forest regions and forest types Leguminosae is the most abundant family (Table 1). Leguminosae are especially abundant in the Guianas in floodplain forests (Table 1) and forests on white sand podzols (an average of 164 ind. in three 450-tree samples), and in fact, in the Guiana Shield in general (Table 1). Over the whole area considered, the abundance of Leguminosae is twice as high as those of the next two most abundant families - Arecaceae and Lecythidaceae, with 9\% and 8\% respectively. These data also show that just three families amount to nearly one-third of all trees in Amazonia. In forests on white sand podzols in the Guiana Shield $(n=3)$, Leguminosae and Bombacaceae are very abundant (163-165 and 72-130 individuals in 450-tree samples respectively). Arecaceae and Moraceae are most abundant in the terra firme forest of WA, as are Myristicaceae and Rubiaceae. Sapotaceae are most abundantly found in CA and Burseraceae in both CA and EA. Lecythidaceae and Chrysobalanaceae are most abundant in CA and GS. Arecaceae dominate the floodplain forests in both WA and EA (Table 1) and also the swamp forests in WA (data not shown) and GS (van Andel, unpubl. data).

The DCA, PGA and MDS ordinations gave very similar results and the scores of the plots on the first axis were highly correlated (Pearson's r: DCA-PCA 0.983; DCA-MDS -0.954). Because there are distinct floristic differences between $\mathrm{TF}$ and FL plots (Table 1) the results of the TF and FL ordination are discussed separately. 
Table 1. Average number of individuals of 16 major tree families in random samples of 450 trees on small plots in terra firme plots in four Amazonian regions. Abbreviations: WA, western Amazonia; CA, central Amazonia; EA, eastern Amazonia; GS, Guiana Shield. The families have been ordered according to their abundance from WA to GS. Differences in the superscript following the abundance indicate significant differences between regions. $\mathrm{P}$ indicates the level of significance as tested with one way ANOVA. Families that show a significant difference between regions are in bold.

\begin{tabular}{|c|c|c|c|c|c|}
\hline & WA & CA & EA & GS & $\mathrm{P}$ \\
\hline \multicolumn{6}{|l|}{ Terra firme forest } \\
\hline Number of plots & 21 & 10 & 11 & 28 & \\
\hline Arecaceae & $51.7^{\mathrm{a}}$ & $13.1^{\mathrm{b}}$ & $10.9^{\mathrm{b}}$ & $10.0^{\mathrm{b}}$ & 0.000 \\
\hline Myristicaceae & $28.7^{\mathrm{a}}$ & $14.6^{\mathrm{ab}}$ & $7.8^{\mathrm{b}}$ & $6.1^{\mathrm{b}}$ & 0.000 \\
\hline Moraceae & $50.6^{\mathrm{a}}$ & $28.6^{\mathrm{b}}$ & $18.8^{\mathrm{b}}$ & $9.0^{\mathrm{b}}$ & 0.000 \\
\hline Rubiaceae & $10.7^{\mathrm{a}}$ & $3.1^{\mathrm{b}}$ & $1.9^{\mathrm{b}}$ & $4.0^{\mathrm{b}}$ & 0.000 \\
\hline Violaceae & 11.6 & 7.6 & 8.5 & 3.4 & 0.305 \\
\hline Sterculiaceae & 11.7 & 3.9 & 11.5 & 5.0 & 0.320 \\
\hline Sapotaceae & $21.3^{\mathrm{b}}$ & $59.8^{\mathrm{a}}$ & $31.7^{\mathrm{b}}$ & $28.3^{\mathrm{b}}$ & 0.000 \\
\hline Euphorbiaceae & 21.3 & 11.8 & 29.7 & 16.8 & 0.104 \\
\hline Meliaceae & 12.1 & 6.8 & 19.3 & 9.4 & 0.176 \\
\hline Burseraceae & $19.3^{\mathrm{b}}$ & $35.2^{\mathrm{a}}$ & $41.5^{\mathrm{a}}$ & $21.0^{\mathrm{b}}$ & 0.007 \\
\hline Lauraceae & 14.3 & 21.2 & 14.0 & 18.9 & 0.337 \\
\hline Bombacaceae & 8.6 & 4.7 & 4.8 & 12.1 & 0.118 \\
\hline Annonaceae & 10.9 & 9.6 & 13.3 & 16.4 & 0.194 \\
\hline Lecythidaceae & $21.2^{\mathrm{b}}$ & $59.7^{\mathrm{a}}$ & $43.5^{\mathrm{b}}$ & $56.7^{\mathrm{a}}$ & 0.001 \\
\hline Leguminosae & $49.3^{\mathrm{b}}$ & $55.9^{\mathrm{ab}}$ & $77.6^{\mathrm{ab}}$ & $94.6^{\mathrm{a}}$ & 0.001 \\
\hline Chrysobalanaceae & $8.4^{\mathrm{b}}$ & $27.5^{\mathrm{a}}$ & $12.2^{\mathrm{b}}$ & $38.4^{\mathrm{a}}$ & 0.000 \\
\hline \multicolumn{6}{|l|}{ Floodplain forest } \\
\hline Number of plots & 16 & 3 & 3 & 2 & \\
\hline Rubiaceae & 10.1 & 10.7 & 0.0 & 0.0 & 0.185 \\
\hline Moraceae & 34.1 & 33.0 & 4.3 & 0.0 & 0.087 \\
\hline Myristicaceae & 25.4 & 28.0 & 3.0 & 3.0 & 0.087 \\
\hline Violaceae & 5.4 & 4.3 & 0.0 & 1.5 & 0.789 \\
\hline Annonaceae & 27.9 & 29.0 & 0.3 & 7.0 & 0.065 \\
\hline Sapotaceae & 18.1 & 31.3 & 3.7 & 3.0 & 0.060 \\
\hline Sterculiaceae & 9.5 & 6.0 & 7.7 & 2.5 & 0.514 \\
\hline Lauraceae & $9.8^{\mathrm{b}}$ & $32.7^{\mathrm{a}}$ & $0.0^{\mathrm{b}}$ & $8.5^{\mathrm{ab}}$ & 0.008 \\
\hline Euphorbiaceae & 20.8 & 33.3 & 21.0 & 9.5 & 0.604 \\
\hline Arecaceae & $100.1^{\mathrm{ab}}$ & $17.3^{\mathrm{b}}$ & $181.7^{\mathrm{a}}$ & $0.0^{\mathrm{b}}$ & 0.008 \\
\hline Bombacaceae & 22.8 & 7.0 & 16.0 & 14.0 & 0.676 \\
\hline Chrysobalanaceae & 6.9 & 15.0 & 31.3 & 2.0 & 0.160 \\
\hline Burseraceae & $3.0^{\mathrm{b}}$ & $11.3^{\mathrm{a}}$ & $19.3^{\mathrm{a}}$ & $6.5^{\mathrm{a}}$ & 0.002 \\
\hline Meliaceae & 16.7 & 7.0 & 22.0 & 31.0 & 0.402 \\
\hline Lecythidaceae & $4.8^{\mathrm{b}}$ & $43.0^{\mathrm{a}}$ & $16.7^{\mathrm{ab}}$ & $48.5^{\mathrm{a}}$ & 0.000 \\
\hline Leguminosae & $44.8^{\mathrm{b}}$ & $49.0^{\mathrm{b}}$ & $83.0^{\mathrm{b}}$ & $236.0^{\mathrm{a}}$ & 0.000 \\
\hline
\end{tabular}

The ordination with MDS produced the best separation of TF plots by area in a bi-plot (Figures 1, 2). Explained variance is c. 27\% for axis 1 and $11 \%$ for axis 2, based on PCA and DCA ordination. In the MDS ordination (as in the others) the plots are ordered more or less in a north-east to south-west direction (Figure 1). Plots with a low score are found in the Guianas, EA and CA. Plots with a high score are mainly found in WA. However, the more central portion of WA has lower scores than the more southern and northern parts. Although a linear spatial regression explains the variation of MDS plots scores relatively well $(\mathrm{r}=0.699, \mathrm{P}<0.001$, Figure 1$)$, a quadratic function explains the variation better $(\mathrm{r}=0.754, \mathrm{P}<0.001)$. The linear component can be interpreted as the main gradient from Guyana-east Venezuela to Peru-Bolivia 
(Figure 1). The quadratic model shows anisotropy caused by the fact that the plots on the edge of western Amazonia and the Guiana Shield are more similar to the plots in the Guianas than the plots in Peru. Auto-correlation analysis of MDS plot scores results in an exponential variogram $(\mathrm{r}=0.81, \mathrm{P}<0.01)$, suggesting that none of the plots are really spatially independent (no matter the distance) but rather are ordered on a gradient.

Families that show the strongest correlation with MDS axis 1 are (Table 2): Arecaceae, Myristicaceae and Moraceae, increasing in abundance from the Guianas towards western Amazonia, and Chrysobalanaceae and Lecythidaceae increasing towards the Guianas. Sapotaceae show an optimum in CA indicated by only a significant 2nd order polynomial. Sterculiaceae and Violaceae show highest abundance at the two ends of the gradient but the significance is mainly caused by one point with very high abundance.

The gradient for the $24 \mathrm{FL}$ plots was less 'method-independent' (r: DCAN-MPGA -0.612; DCA-MDS 0.891). However, the explained variance (DCA) was still $41 \%$ for the first two axes together. Arecaceae, Lecythidaceae and Leguminosae had strongest correlation with the first axis. Because all FL plots in EA were also strongly dominated by Arecaceae, WA and EA plots were always close together in the bi-plots.

\section{Diversity patterns}

The range found in Fisher's alpha (in the complete data-set) was quite large - from 3.6 (GS: N (no. of individuals) = 395, S (no. of species) =17) to 221.8 (CA: $\mathrm{N}=769, \mathrm{~S}=322$ ). Plots with very high alpha-diversity (Fisher's alpha $>200)$ are found in a wide area from western to central Amazonia (Figure 3). These plots include the hyper-diverse plots in Peru (Gentry 1988a)

Table 2. Coefficients of determination $\left(\mathrm{r}^{2}\right)$ of a multiple regression of the scores of plots on the first axis of the multidimensional scaling and family abundance on these $70 \mathrm{TF}$ plots in Amazonia and the Guiana Shield area. Significant regressions (with Bonferroni correction) are given in bold. With four families the 2nd order polynomial is necessary to describe the relationship between axis and abundance well. Sapotaceae and Leguminosae show an optimum in the centre-axis scores, Sterculiaceae and Violaceae a minimum.

\begin{tabular}{lcc}
\hline Family & 1st order & 2nd order significance \\
\hline Annonaceae & 0.04 & $0.05 \mathrm{~ns}$ \\
Arecaceae & $\mathbf{0 . 7 4}$ & $\mathbf{0 . 7 8}^{*}$ \\
Bombacaceae & 0.00 & $0.00 \mathrm{~ns}$ \\
Burseraceae & 0.01 & $0.11 \mathrm{~ns}$ \\
Chrysobalanaceae & $\mathbf{0 . 3 9}$ & $\mathbf{0 . 5 5}^{*}$ \\
Euphorbiaceae & 0.01 & $0.01 \mathrm{~ns}$ \\
Lauraceae & 0.11 & $0.12 \mathrm{~ns}$ \\
Lecythidaceae & $\mathbf{0 . 5 8}$ & $\mathbf{0 . 6 8} *$ \\
Leguminosae & $\mathbf{0 . 0 6}$ & $\mathbf{0 . 1 9}$ \\
Meliaceae & 0.08 & $0.11 \mathrm{~ns}$ \\
Moraceae & $\mathbf{0 . 5 2}$ & $\mathbf{0 . 5 2} *$ \\
Myristicaceae & $\mathbf{0 . 1 7}$ & $\mathbf{0 . 1 7} *$ \\
Rubiaceae & 0.13 & $0.14 \mathrm{~ns}$ \\
Sapotaceae & 0.13 & $\mathbf{0 . 1 8 *}$ \\
Sterculiaceae & 0.09 & $\mathbf{0 . 1 6}$ \\
Violaceae & 0.13 & $\mathbf{0 . 2 7} *$ \\
\hline
\end{tabular}


and Ecuador (Valencia et al. 1994) but also in Brazil (Amaral 1996, Oliviera \& Mori 1999). Most plots in eastern Amazonia, the Guianas and other areas have much lower diversity, except for some plots in the Chocó (Faber-Langendoen \& Gentry 1991) and French Guiana (Mori \& Boom 1987). The variogram constructed for alpha-diversity of TF plots suggests autocorrelation up to 300$500 \mathrm{~km}$ but contains a substantial amount of noise at larger distances. For interpolation of TF diversity an interdistance-weighting up to $500 \mathrm{~km}$ is used in Figure 3.

Both region (WA+RO, CA, EA, GS) and forest type (only FL and TF tested) had a significant effect on Fisher's alpha (Regions: $\mathrm{F}_{[3,137]}=12.23, \mathrm{P}<0.001$; Forest type: $\mathrm{F}_{[1,137]}=23.24, \mathrm{P} \ll 0.001$; No interaction: $\mathrm{F}_{[1,137]}=1.45, \mathrm{P}=0.23$ ) when tested together for the core Amazonian plots $\left(8^{\circ} \mathrm{S}-8^{\circ} \mathrm{N}\right.$, rainfall $\geqslant 2000$

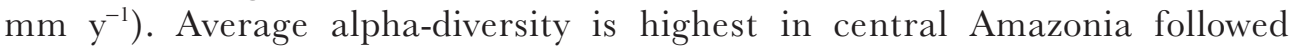
closely by western Amazonia (Table 3). The most diverse floodplain forests are found, on average, in western Amazonia. The plots on the Guiana Shield and eastern Amazonia have low diversities for terra firme and floodplain forest, as well as forest on white sand podzols and in swamps (as compared to WA and CA). Post-hoc comparison (Scheffé's test) shows that in terms of alpha-diversity there are two regions. CA and WA plots are not significantly different from each other and neither are EA and GS plots. Between the CA-WA on one hand and EA-GS on the other all combinations are significantly different. Thus, EA and GS plots have significantly lower diversity than WA and CA plots.

$\mathrm{TF}$ plots have significantly higher diversity than FL plots in all regions. Swamp plots appear to have lowest diversity, while white sand podzols have higher diversity than floodplains. Neither were tested statistically because of their low numbers.

The overall relationship between rainfall (complete range) and diversity (all plots in WA+RO, CA, EA and GS) was very weak (Figure 4a). Rainfall explained $c .8 \%$ of the variation in Fisher's alpha $(\mathrm{r}=0.279 \mathrm{df}=241, \mathrm{P}<$ $0.001)$. Two very rich plots in WA have a large influence on the correlation outcome and show very high Cook's distances $(0.14,0.15$ vs. an average of 0.05$)$ and can be considered as statistical outliers. But even with omission of four plots with Fisher's alpha $>200$, the influence of rainfall is still significant $(r=$

Table 3. Average alpha-diversity for 1 -ha plots in core Amazonian rain forest $\left(8^{\circ} \mathrm{S}-8^{\circ} \mathrm{N}\right.$, annual rainfall $\geqslant$ 2000 mm). Abbreviations: GS, Guiana Shield; EA, eastern Amazonia; CA, central Amazonia; WA, western Amazonia; TF, terra firme; FL, floodplain forest; PZ, forest on white sand podzols; SW, swamp forest. Maximum Fisher's-alpha per forest per region in parentheses. Superscripts indicate differences in average Fisher's-alpha between the regions as tested with Scheffé's post-hoc test $(\mathrm{P}<0.05)$; $\mathrm{P}$ indicates significance for single-way ANOVA per forest type.

\begin{tabular}{lccccc}
\hline Forest & WA & CA & EA & GS & P \\
\hline TF & $124.5(221.1)^{\mathrm{a}}$ & $126.3(221.8)^{\mathrm{a}}$ & $56.0(123.6)^{\mathrm{b}}$ & $51.9(155.5)^{\mathrm{b}}$ & $<0.001$ \\
FL & $78.7(131.7)^{\mathrm{a}}$ & $46.1(109.4)^{\mathrm{ab}}$ & $20.8(24.6)^{\mathrm{ab}}$ & $16.7(22.7)^{\mathrm{b}}$ & $<0.01$ \\
PZ & $99.7(1422)^{\mathrm{a}}$ & & & $24.3(39.1)^{\mathrm{b}}$ & $<0.05$ \\
SW & $33.7(67.2)$ & & & $7.5(8.2)$ & $\mathrm{ns}$ \\
\hline
\end{tabular}



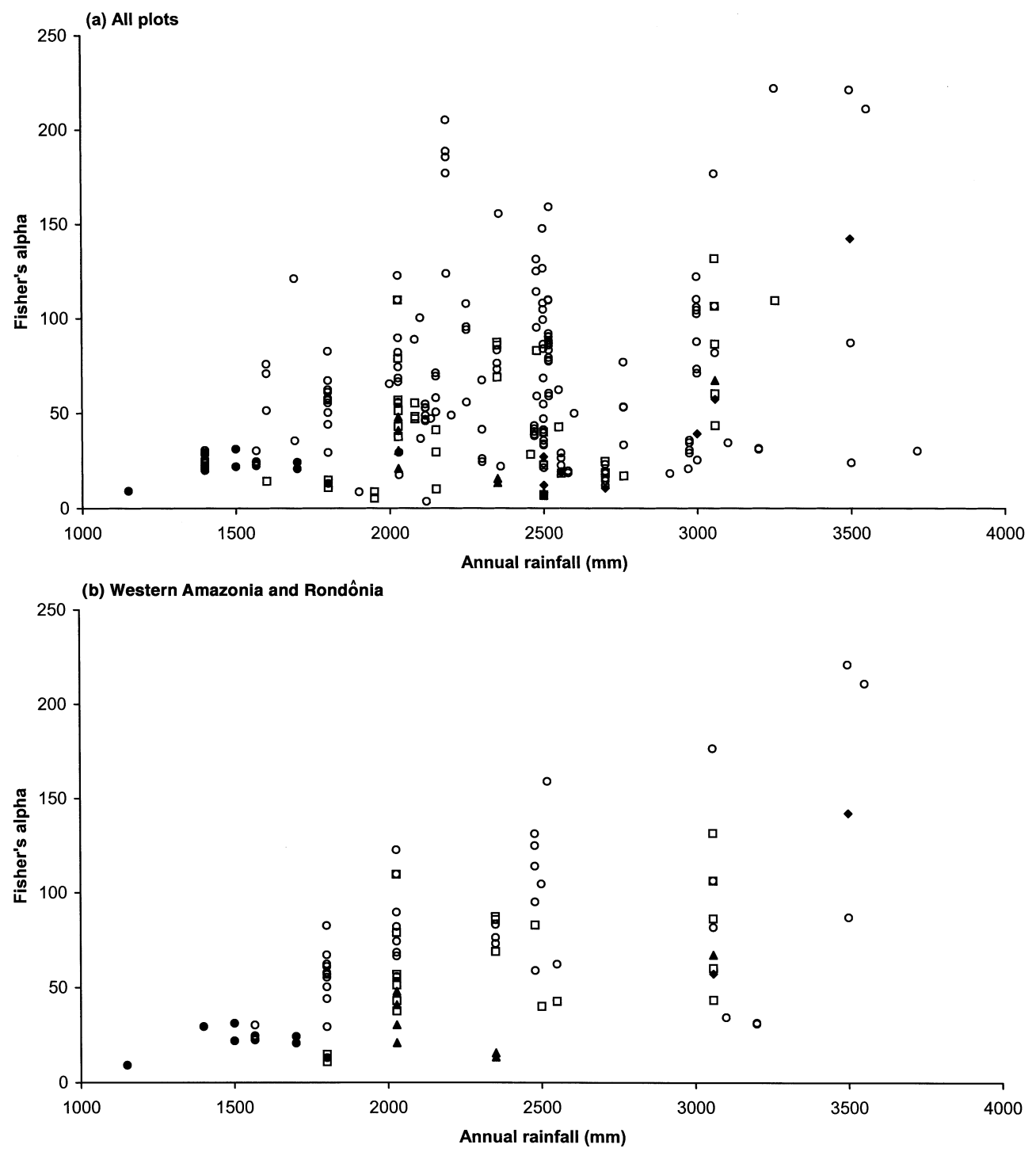

Figure 4. The relationship between annual rainfall $\left(\mathrm{mm} \mathrm{y}^{-1}\right)$ and Fisher's alpha for (a) all plots in western, central, eastern Amazonia and the Guiana Shield, (b) plots in western Amazonia and Rondônia, (c) central Amazonia, (d) eastern Amazonia, (e) Guiana Shield. Symbols: $\bigcirc$, terra firme; $\square$, floodplain; $\boldsymbol{\nabla}$, podzol; $\boldsymbol{\Delta}$ swamp; dry forest.

$0.211, \mathrm{df}=237, \mathrm{P}<0.01)$. Both for $\mathrm{TF}$ and $\mathrm{FL}$ plots rainfall shows a significant correlation with Fisher's alpha $(\mathrm{r}=0.244, \mathrm{df}=172, \mathrm{P}<0.01 ; \mathrm{r}=0.445, \mathrm{df}=$ $37, \mathrm{P}<0.01)$. In the case of TF plots the relationship is no longer significant when the plots with annual rainfall $<2000 \mathrm{~mm}$ (in the dry regions of Bolivia and Venezuela) are removed $(\mathrm{r}=0.041, \mathrm{df}=138, \mathrm{P}>0.05)$.

In WA+RO (Figure 4b) rainfall has a significant correlation with Fisher's alpha for all plots $(\mathrm{r}=0.576, \mathrm{df}=79, \mathrm{P}<0.001)$. This is also the case for all 

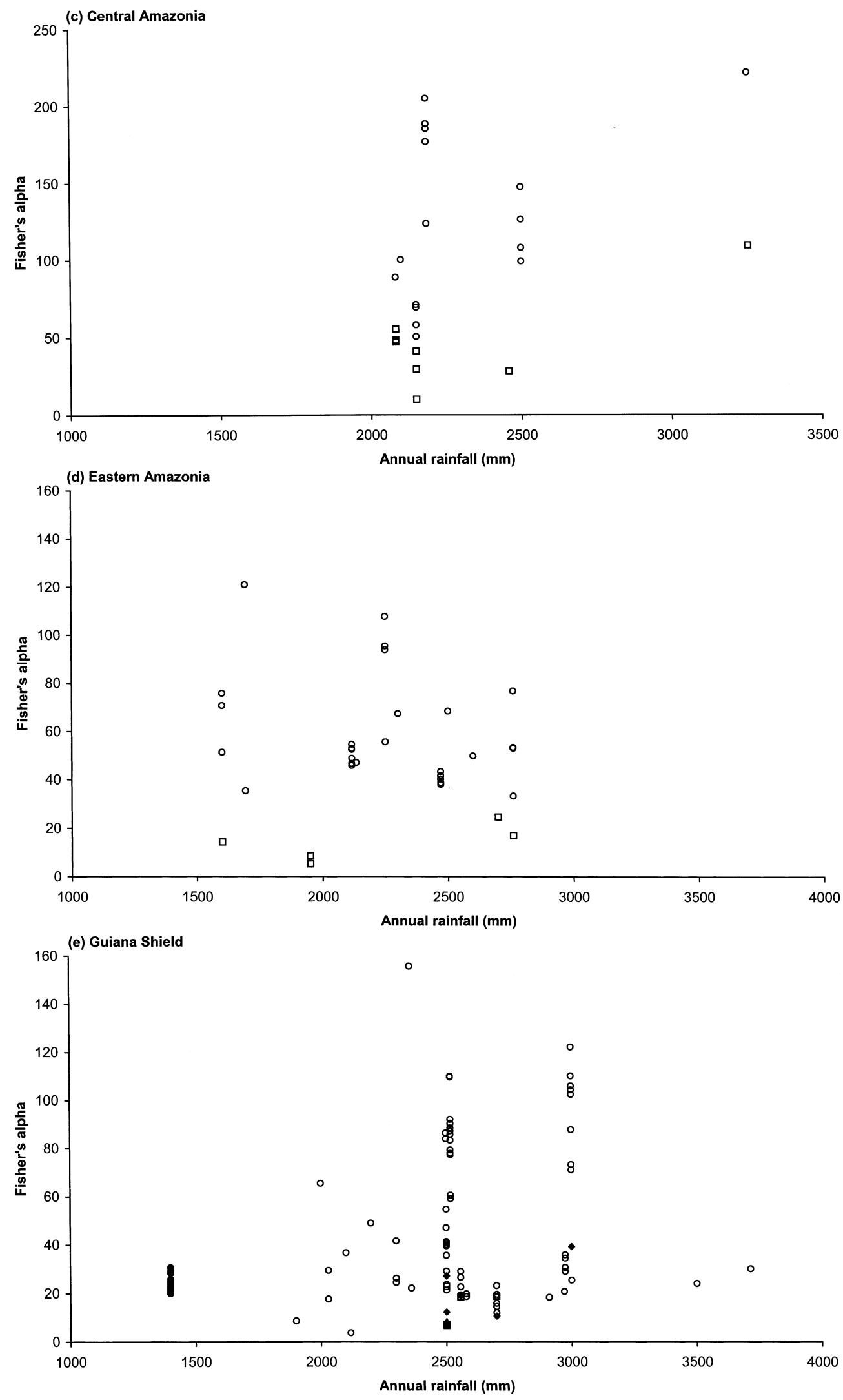
the TF plots $(\mathrm{r}=0.568, \mathrm{df}=42, \mathrm{P}<0.01)$ even when the two outlier plots are removed $(\mathrm{r}=0.391, \mathrm{df}=40, \mathrm{P}<0.05)$. There is no significant correlation when only plots with rainfall $\geqslant 2000 \mathrm{~mm}$ are $\mathrm{used}(\mathrm{r}=0.305, \mathrm{df}=27, \mathrm{P}>0.05)$.

In CA (Figure 4c) there is no significant correlation between rain and Fisher's alpha, when all plots or TF plots are analysed. There is a significant correlation for the FL plots but this is caused by only one datum point and is considered doubtful. There is no significant relationship between rainfall and Fisher's alpha in EA for all plots, TF plots or FL plots (Figure 4d).

In the GS plots (Figure 4e) there is a small significant correlation $(r=0.257$, $\mathrm{df}=98, \mathrm{P}<0.01)$ between rainfall and Fisher's alpha, but not if the dry forest plots (rain $<1500 \mathrm{~mm}$ ) in Venezuela are removed $(\mathrm{r}=0.138$, df $=85, \mathrm{P}>$ 0.05). The same is true when TF plots are analysed separately. The GS plots contain one clear outlier, Saül, with a Fisher's alpha of 155.5. Outliers in terms of rainfall are Rio Caura $\left(3715 \mathrm{~mm} \mathrm{y}^{-1}\right)$ and San Carlos $\left(3500 \mathrm{~mm} \mathrm{y}^{-1}\right)$, both with very low diversity.

The range in diversity (Fisher's alpha) within one area can be substantial but is remarkably stable in other areas (Appendix 1). A few examples for terra firme plots: Manaus 123.6-205.1 $(n=4)$; Nouragues 70.9-122.0 ( $n=8)$; St Elie 58.9-109.8 ( $\mathrm{n}=16$ ); Manu Pakitza 55.6 - 122.6 ( $\mathrm{n}=5)$; Mabura Hill 8.4$11.6(\mathrm{n}=3)$. Central Guyana shows consistently low figures for alpha-diversity (Appendix 1), with species numbers almost always $<100 \mathrm{ha}^{-1}$. Similarly low values are found in Venezuelan Guayana lowland forests. Moving eastwards through Suriname to French Guiana diversity in the Guianas increases steadily. The sample with highest diversity in the Guianas is found near Saül, French Guiana with a Fisher's alpha of 155.5 (Appendix 1).

\section{DISGUSSION}

In the neotropics a total of 292 plant families occur, 140 of which contain tree species (Maas \& Westra 1993). Only 16 families out of this high number make up close to $80 \%$ of all the tree individuals that grow $\geqslant 10 \mathrm{~cm} \mathrm{DBH}$. These few families dominate most neotropical forest sites, confirming Gentry's (1990) observation that neotropical forests are floristically very similar. However similar though, there are clear large-scale patterns in the abundance of important tree families in lowland Amazonian forest. Leguminosae, Lecythidaceae and Chrysobalanaceae dominate in eastern Amazonia and Guiana Shield terra firme and floodplain forests. Palms, Moraceae, and to a lesser extent Myristicaceae dominate the forests of western Amazonia. This result is in full agreement with Terborgh \& Andresen (1998) and firmly establishes the unique composition of the flora on the Guiana Shield area as being one end of a floristic gradient. The patterns in abundance correspond to species richness in the families. Palms are also more species-rich on the plots in WA (see references in Appendix 1) and in WA as a whole (Kahn \& de Granville 1992). Chrysobalanaceae (Licania) are not only common in the Guianas, they also attain high diversity there (Prance 1986). However, whereas Lecythidaceae are most abundant 
in Guyana, they have highest diversities in central Amazonia (Mori et al. in press).

If rainfall is not a good predictor of large-scale patterns in alpha-diversity in Amazonia, what is? We briefly discuss four possible causes, specifically comparing the Guiana Shield area with central and western Amazonia.

\section{Primary productivity}

Primary productivity is thought to have an important influence on species richness (e.g. Huston 1994, Rosenzweig 1995) and Phillips et al. (1994) found that the most productive sites in western Amazonia did indeed have highest species diversity. A higher turnover, leading to escape from competitive conclusion could be the mechanism (Huston 1994, Phillips et al. 1994). Unfortunately, rainfall, seasonality, temperature and soil quality may all independently affect productivity.

Large-scale differences in NPP, between WA, CA and GS appear to be nonexistent (see Raich et al. 1991). Most soils in the Amazon basin are poor, rainfall ranges and temperatures are similar. However, the NPP as calculated by Raich et al. (1991) is based upon the FAO soil map of the world, which greatly underestimates the presence of ultisols in the western Amazon, which are all classified as oxisols (Richter \& Babbar 1991). Based on the data we have, we cannot conclude that differences in productivity are the cause of differences in the large-scale diversity patterns over Amazonia.

Rainfall, as a proxy estimate for productivity, has been found to correlate strongly with diversity (Clinebell et al. 1995). We find rainfall to be a poor estimator for tree alpha-diversity, especially when only plots with rainfall $\geqslant 2000 \mathrm{~mm}$ are taken into account, which would include most plots with rain forest. There is a difference in tree alpha-diversity between forests with very low rainfall, dry forests, and the forests with higher rainfall, rain forests. However, considering only rain forests, we cannot agree with Clinebell et al. (1995) that 'Wet forests with an ample year-round moisture harbour the greatest number of woody plant species and should be a focus of conservation efforts'. Forest in central Amazonia with lower annual, more seasonal, precipitation, such as around Manaus can be just as species-rich as the aseasonal very wet forests of western Amazonia, and possibly several areas in between (Figure 3). On the other hand under a similarly large range in rainfall, tree alpha-diversity in the Guianas is consistently lower than that of CA or WA. In addition to that, such a simple model easily leads to overemphasis of just one measure of diversity as a tool for preservation and neglects phytogeographic differences and patterns of endemism (see below).

\section{Ecosystem dynamics}

Both intermediate disturbance hypothesis and dynamic equilibrium theory predict higher species richness with intermediate disturbances that delay or prevent competitive exclusion (Huston 1994). Higher turnover has indeed been 
reported from forests with higher diversity (Phillips et al. 1994). But more recently such high diversities have also been reported from forests with very low dynamics (Oliviera 1997, Rankin-de Merona et al. 1990). Some community characteristics, related to shade tolerance such as an average large seed size (Hammond \& Brown 1995) have been put forward as evidence that the Guianas suffer less large-scale disturbances than WA. Also within Guyana a decline in alpha-diversity is correlated with an increase in average community seed size and wood density, and a decrease in pioneers (H. ter Steege \& D. S. Hammond, unpubl. data). This gradient in diversity has also been interpreted as a gradient in disturbance, possibly related to prehistoric Amerindian activities (H. ter Steege \& D. S. Hammond, unpubl. data). If higher turnover should also lead to shorter generation periods this could also affect diversity at longer (evolutionary) time scales (Rohde 1992). Marzluff \& Dial (1991) indeed found that short generation time (and the ability to colonize new resources) was associated with higher diversity.

Area

Area probably holds more influence over the origin and maintenance of diversity at large and small scales than currently appreciated. It may, for example, be largely responsible for the latitudinal gradient (Rosenzweig 1995, Terborgh 1973). Larger areas should have more species for four reasons - two pertaining to speciation rates and two pertaining to extinction rates (Rosenzweig 1995). Speciation rates in larger areas are higher because (a) larger areas are more likely to contain geographical barriers, important for allopatric speciation and (b) species with larger ranges have more genetic variation and seem to evolve faster. Extinction rates in large areas/populations are lower because (c) larger ranges lead to larger populations that are less likely to go extinct due to random population fluctuations and (d) larger ranges encompass more niche refugia, where populations may reside when large changes (e.g. climatic) occur.

Because species richness in smaller areas is also influenced by the size of the total area it belongs to, caused by sink-source relationships, or mass effects (Rosenzweig 1995, Zobel 1997), 1-ha plots in large forest tracts should have more species than those of smaller tracts. If we carefully consider the location of the Guianas in relation to the rest of Amazonia, a much larger area, three barriers exist between them. From the north to the south these are: the Llanos, the Guayana Highlands and the Transverse Dry Belt (Pires 1997). Eastern Amazonia is separated from Central Amazonia by the same Transverse Dry Belt in the west and is bordered on the south by dry deciduous forest. The mouth of the Amazon effectively separates Eastern Amazonia and the Guiana Shield areas. Also the river drainage system of the three Guianas is almost completely separated from the Amazon drainage (e.g. Rosales-Godoy et al. 1999). While the separation is by far not 'species-tight' only a pattern of this scale can explain the consistent differences in species diversity between eastern 
Amazonia and the Guiana Shield on one hand and central and western Amazonia on the other hand.

Area may also help to explain why certain forest types are richer than others. Obvious conclusions sometimes force themselves upon us. We generally believe that floodplains and mangroves are poor places to live with severe physiological constraints imposed by perpetual waterlogging and regular submersion by the seawater, allegedly limiting the pool of species that can grow (e.g. Clinebell $e t$ al. 1995). But is this true? Mangroves and floodplains are also fringe habitats, small in area and heavily fragmented. Could this contribute to their low species richness? Thinking long-term and large-scale, most likely it does (Rosenzweig 1995, Terborgh 1973 and see above arguments). We would be surprised that, if mangroves covered an area the size of Amazonia, they would be as poor in species as they are now. In fact, where mangroves are more extensive (the Pacific) they are indeed much richer in species (Tomlinson 1986).

In the light of the above, it should not be surprising that the forest that covers most of the 'typical soils' of Amazonia (ultisols and oxisols) is also the richest, not only in CA and WA but also within the Guianan area. Floodplain forests, swamps and forests on white sands are much smaller in extent (Table 4) and more fragmented and for reasons stated above that should explain to some extent their lower species richness. White sand podzols cover only $2.8 \%$ of the Amazon basin and $7.9 \%$ in Guyana (Table 4). Because of obvious ecological differences, they harbour, despite their low species richness, a flora relatively rich in endemics (Huber 1995, Lleras 1997, ter Steege 1998a, ter Steege et al. 2000). Had the situation been reversed with most of Amazonia being white sand and just a few areas with ultisols/oxisols, undoubtedly the latter would have been far poorer in species (we probably would have attributed this to the 'obvious' aluminium toxicity of such soils). Floodplains are more species-rich where they cover larger areas in WA. Within that area they had even far greater extent in historical times (Rosales-Godoy et al. 1999).

Endemics are most often found in small distinct habitats, often fragmented ('ecological islands'), such as white sand areas, serpentine rock, cloud forests (Gentry 1992, Huber 1995, Lleras 1997, ter Steege 1998a, ter Steege et al. 2000). With the same reasoning mangrove-, floodplain- and swamp-restricted species could be considered 'ecological endemics'. Because small habitat areas are likely to have fewer species (see above) we expect the relationship between

Table 4. Percentage of soil types in four neotropical areas largely covered with rain forest. Oxisols and ultisols cover the majority of these areas and are particularly extensive in the Brazilian Amazon. (Data: Guyana, Gross-Braun (1965); Brazil, Richter \& Babbar (1991); Colombia, Duivenvoorden \& Lips (1998); Peru, Salo et al. (1986).)

\begin{tabular}{lccccc}
\hline & Podzols & FL & O/U & Lithosols & Total area $\left(\mathrm{km}^{2}\right)$ \\
\hline Guyana & 7.9 & 8.2 & 51.5 & 16.7 & 214056 \\
Brazilian Amazon & 2.8 & 7.1 & 71.4 & 4.5 & 4614100 \\
Colombian Amazon (pro porte) & 4.1 & 14.3 & 72.7 & $8.2 ?$ & 6700 \\
Peruvian Amazon & na & 12.0 & na & na & 515800 \\
\hline
\end{tabular}


endemism and diversity to be negative within a phytogeographic region. Between regions or continents, i.e. areas with a separate evolutionary history, the relationship is undoubtedly positive: the more species the more endemics.

Two factors, area and disturbance regime, may be responsible for a large part of the differences in alpha-diversity found between the Guiana Shield area and eastern Amazonia as compared to central and western Amazonia. Very recently a third potential factor was added to this list: the 'mid-domain effect' (Colwell \& Lees 2000). This model suggests that even without environmental gradients species richness should peak in the centre of a large biogeographic area and is based on the range-size distribution found in species. The causes for gradient in family composition could be both ecological and historical (Terborgh \& Andresen 1998). Arecaceae and Moraceae are very abundant and species-rich in western Amazonia but they are not absent in the eastern areas. In several floodplain sites Arecaceae even dominate the forests in EA and the coastal swamps of the Guianas. Similarly, Chrysobalanaceae and Lecythidaceae are not absent from western Amazonia but less abundant. But why are Moraceae more abundant and rich in species in WA and are Chrysobalanaceae, Lecythidaceae and Leguminosae more abundant in GS? We believe that the disturbance regime may be partly responsible (Hammond \& Brown 1995; H. ter Steege \& D. S. Hammond, unpubl. data). Higher dynamics may allow members of families with pioneer-like characteristics such as light wood, small seeds, and short generation times (many Moraceae) to dominate over the slower growing species from the dense wooded and large-seeded families (Chrysobalanaceae, Lecythidaceae). In Guyana we found clear patterns of average community seed size, wood density and diversity (H. ter Steege \& D. S. Hammond, unpubl. data). At the larger scale, the seed size spectrum of Guianan forest is also strikingly different from that of Western Amazonia (Hammond \& Brown 1995). Fast growing species tend to have short generation times, which may promote species richness of such taxa (Marzluff \& Dial 1991). This may be an additional cause for the high diversity in western Amazonia.

\section{ACKNOWLEDGEMENTS}

We thank all our colleagues who have published materials that we needed so much to carry out the analyses. We hope that this publication will stimulate others to continue the search for causal effects on diversity and floristic patterns. We also thank Mark van Nieuwstadt, René Verburg for discussions and comment, Roderick Zagt, Marinus Werger, Thijs Pons, John Terborgh, Kalle Ruokolainen, David Newbery and two anonymous reviewers for critical and stimulating comments on the manuscript, and Pitman et al. for their unpublished manuscript.

\section{LITERATURE CITED}

ABSY, M. L., PRANCE, G. T. \& BARBOSA, E. M. 1987. Inventário florístico de floresta natural na área da estrada Cuiabá-Porto Velho (BR - 364). Acta Amazônica 16/17(suppl.):85-121. 
ALMEIDA, S. S., LISBOA, P. L. B. \& SILVA, A. S. 1993. Diversidade florística de uma comunidade arbórea na estação científica 'Ferreira Pena', em Caxiuanã (Pará). Boletim do Museu Paraense Emílio Goeldi. Serie Botânica 9:93-128.

AMARAL, I. L. 1996. Diversidade florística em floresta de terra firme, na região de Urucu - AM. Dissertação de Mestrado, Instituto Nacional de Pesquisas da Amazônia (INPA) /Fundação Universidade do Amazônas (FUA). Manaus.

AYRES, J. M. 1981. Observações sobre a ecologia e o comportamento doc Guciús (Chiropotes satanes e C. satanus). MSc dissertation, INPA, Manaus.

AYRES, J. M. 1993. As matas da Várzea do Mamirauá. MCT-CNPq/ Sociedade Civil Mamirauá. Brasilia.

BALEE, W. 1986. Análise preliminar de inventário florestal e a etnobotânica Ka'apor (Maranhão). Boletim do Museu Paraense Emílio Goeldi. Serie Botânica 2:141-167.

BALEE, W. 1987. A entnobotânica quantitativa dos índios Tembé (Rio Gurupi, Pará). Boletim do Museu Paraense Emílio Goeldi. Serie Botânica 3:29-50.

BALEE, W. \& CAMPBELL, D. G. 1990. Evidence for the successional status of liana forest (Xingu river basin, Amazonian Brazil). Biotropica 22:36-47.

BALSLEV, H., LUTEYN, J., OLLGAARD, B. \& HOLM-NIELSEN, L. B. 1987. Composition and structure of adjacent unflooded and floodplain forest in Amazonian Ecuador. Opera Botanica 92:37-57.

BAlSleV, H., VAlENCIA, R., PAZ Y MINO, G., CHRISTENSEN, H. \& NIELSEN, I. 1998. Species count of vascular plants in one hectare of humid lowland forest in Amazonian Ecuador. Pp. 585-594 in Dallmeier, F. \& Comiskey, J. A. (eds). Forest biodiversity in North, Central and South America, and the Caribbean. Research and monitoring. MAB Series Vol. 21. UNESCO, Paris.

BERGMANS, F. \& VROOMANS, V. 1995. Availability and sustainability of forest resources: a research to the structure and species composition of a north Bolivian Amazon forest and its actual and future resource availability. Thesis, Larenstein Agricultural College, Velp, The Netherlands.

BLACK, G. A., DOBZHANSKY, T. H. \& PAVAN, G. 1950. Some attempts to estimate species diversity and population density of trees in Amazonian forests. Botanical Gazette 111:413-425.

BONGERS, F., POPMA, J., MEAVE DEL CASTILLO, J. \& CARABIAS, J. 1988. Structure and floristic composition of the lowland tropical rain forest of Los Tuxtlas, Mexico. Vegetatio 74:55-80.

BOOM, B. M. 1986. A forest inventory in Amazonian Bolivia. Biotropica 18:287-294.

BUSH, M. B. 1994. Amazonian speciation: a necessarily complex model. Journal of Biogeography $21: 5-17$.

CAIN, S. A., DE OLIVEIRA CASTRO, M., MURÇA PIRES, J. \& DA SILVA, N. T. 1956. Application of some phytosociological techniques to Brazilian rain forest. American Journal of Botany 43:911-941.

CAMPBELL, D. G., DALY, D. G., PRANCE, G. T. \& UBIRAJARA, N. M. 1986. Quantitative ecological inventory of terra firme and varzea tropical forest on the Rio Xingu, Brazilian Amazon. Brittonia 38:369-393.

CAMPBELL, D. G., STONE, J. L. \& ROSAS, A. 1992. A comparison of the phytosociology and dynamics of three floodplain (varzea) forests of known ages, Rio Jurua, western Brazilian Amazon. Botanical Journal of the Linnean Society 108:213-237.

CASTELlanOS, H. G. 1998. Floristic composition and structure, tree diversity, and the relationship between floristic distribution and soil factors in El Caura Forest Reserve, southern Venezuela. Pp. 507-533 in Dallmeier, F. \& Comiskey, J. A. (eds). Forest biodiversity in North, Central and South America, and the Caribbean. Research and monitoring. MAB Series Vol. 21. UNESCO, Paris.

CERÓN, C. E. \& MONTALVO, C. A. 1997. Composición y estructura de una hectárea de bosque en la Amazonía Ecuatoriana - con información etnobotánica de los Huaorani Pp. 153-172 in Valencia, R. \& Balslev, H. (eds). Estudios sobre diversidad de plantas. Memorias de II congreso Ecuatoriana de Botánica. Pontificia Universidad Católica del Ecuador, Quito.

Clinebell, R. R., PHILliPS, O. L., GENTRY, A. H., STARK, N. \& ZUURING, H. 1995. Prediction of neotropical tree and liana species richness from soil and climatic data. Biodiversity and Conservation 4:56-90.

GOLWELL, R. K. \& LEES, D. C. 2000. The mid-domain effect: geometric constraints on the geography of species richness. Trends in Ecology and Evolution 15:70-76.

COMISKEY, J. A., AYMARD, G. \& DALLMEIER, F. 1994. Structure and composition of lowland mixed forest in the Kwakwani region of Guyana. Biollonia 10:13-28.

CONDIT, R., FOSTER, R. B., HUBbElL, S. P., SUKUMAR, R., LEIGH, E. G., MANOKARAN, N., LOO DE LAO, S., LAFRANKIE, J. V. \& ASHTON, P. S. 1998. Assessing forest diversity on small plots: calibration using species-individual curves from 50-hectare plots. Pp. 247-268 in Dallmeier, F. \& Comiskey, J. A. (eds). Forest biodiversity research, monitoring and modelling. Conceptual background and Old World case studies. MAB Series Vol. 20. UNESCO, Paris.

DALLMEIER, F., KABEL, M. \& FOSTER, R. B. 1996. Floristic composition, diversity, mortality and recruitment of different substrates: lowland tropical forest, Pakitza, Rio Manu, Peru. Pp. 61-88 in Wilson, D. E. \& Sandoval, A. (eds). Manu: the diversity of Southeastern Peru. Smithsonian Institution, Washington. 
DAVIS, T. A. W. \& RICHARDS, P. W. 1934. The vegetation of Moraballi creek, British Guiana. An ecological study of a limited area of tropical rain forest. II. Journal of Ecology 22:106-155.

DE WALT, S. J., BOURDY, G., CHAVEZ DE MICHEL, L. R. \& QUENEVO, C. 1999. Ethnobotany of the Tacana. Quantitative inventories of two permanent plots of northwestern Bolivia. Economic Botany 53:237-260.

DUCKE, A. \& BLACK, G. A. 1954. Notas sobre a fitogeografia da Amazônia Brasileira. Boletim Technico IAN (Belém) 29:1-62.

DUIVENVOORDEN, J. F. \& LIPS, J. M. 1995. A land-ecological study of soils, vegetation and plant diversity in Colombian Amazonia. Tropenbos Series 12. Tropenbos Foundation, Wageningen, The Netherlands.

DUIVENVOORDEN, J. F. \& LIPS, J. M. 1998. Mesoscale patterns of tree species diversity in Colombian Amazonia. Pp. 535-549 in Dallmeier, F. \& Comiskey, J. A. (eds). Forest biodiversity in North, Central and South America, and the Caribbean. Research and monitoring. MAB Series Vol. 21. UNESCO, Paris.

EK, R. G. 1997. Botanical diversity in the tropical rain forest of Guyana. Tropenbos-Guyana Programme, Georgetown, Guyana. Ph.D. thesis, Utrecht University, The Netherlands.

EK, R. C. \& TER STEEGE, H. 1998. The flora of the Mabura Hill area, Guyana. Botanischer Jahrbucher fuir Systematik 120:461-502.

FABER-LANGENDOEN, D. \& GENTRY, A. H. 1991. The structure and diversity of rain forests at Bajo Calima, Chocó, western Colombia. Biotropica 23:2-11.

FERREIRA, L. V. 1997. Effects of the duration of flooding on species richness and floristic composition in three hectares in the Jaú National park in floodplain forest in central Amazonia. Biodiversity and Conservation 6:1353-1363.

FERREIRA, L. V. \& PRANCE, G. T. 1998a. Structure and species richness of low-diversity floodplain forest on the Rio Tapajós, Eastern Amazonia, Brazil. Biodiversity and Conservation 7:585-596.

FERREIRA, L. V. \& PRANCE, G. T. 1998b. Species richness and floristic composition in four hectares in the Jaú National Park in upland forests in Central Amazonia. Biodiversity and Conservation 7:1349_ 1364.

FERREIRA, L. V. \& RANKIN-DE MERONA, J. M. 1998. Floristic composition and structure of a one-hectare forest in central Amazonia. Pp. 649-662 in Dallmeier, F. \& Comiskey, J. A. (eds). Forest biodiversity in North, Central and South America, and the Caribbean. Research and monitoring. MAB Series Vol. 21. UNESCO, Paris.

FINOL URDANETA, H. UNDATED. Silvicultura de la Mora de Guiana (Mora gonggrijpii). Faculdad de Ciencias Forestales. Instituto de Silvicultura, Mérida, Venezuela. 73 pp.

FISHER, A. A., GORBET, A. S. \& WILLIAMS, G. B. 1943. The relation between the number of species and the number of individuals in a random sample of an animal population. Journal of Animal Ecology 12:42-58.

GALEANO, G., CEDIEL, J. \& PARDO, M. 1998. Structure and floristic composition of a one-hectare plot of wet forest at the Pacific coast of Choca, Colombia. Pp. 551-568 in Dallmeier, F. \& Comiskey, J. A. (eds). Forest biodiversity in North, Central and South America, and the Caribbean. Research and monitoring. MAB Series Vol. 21. UNESCO, Paris.

GAZEL, M. 1983. Croissance des arbres et productivité des peuplement en forêt dense équatoriale de Guyane. Office National de Forêts, Cayenne, France. 129 pp.

GENTRY, A. H. 1988a. Tree species richness of upper Amazonian forests. Proceedings of the National Academy of Sciences, USA 85:156-159.

GENTRY, A. H. 1988b. Changes in plant community diversity and floristic composition on environmental and geographical gradients. Annals of the Missouri Botanical Garden 75:1-34.

GENTRY, A. H. 1990. Floristic similarities and differences between southern Central America and upper and central Amazonia. Pp. 141-157 in Gentry, A. H. (ed.). Four neotropical rain forests. Yale University Press, New Haven.

GENTRY, A. H. 1992. Tropical forest biodiversity: distributional patterns and their conservational significance. Oikos 63:19-28.

GENTRY, A. H. \& TERBORGH, J. 1990. Composition and dynamics of the Cocha Cashu 'mature' floodplain forest. Pp. 542-564 in Gentry, A. H. (ed.). Four neotropical rain forests. Yale University Press, New Haven.

GIVNISH, T. J. 1999. On the causes of gradients in tropical tree diversity. Journal of Ecology 87:193-210.

GROSS-BRAUN, E. H., DERTING, J. \& SUGGETT, R. (1965). Report of the soil survey project of British Guiana VII: A report to accompany a general soil map of British Guiana. FAO, Rome.

HAFFER, J. 1997. Alternative models of vertebrate speciation in Amazonia: an overview. Biodiversity and Conservation 6:451-476.

HALL, J. B. \& SWAINE, M. D. 1976. Classification and ecology of closed-canopy forest in Ghana. Journal of Ecology 64:913-951.

HAMMOND, D. S. \& BROWN, V. K. 1995. Seed size of woody plants in relation to disturbance, dispersal, soil type in wet neotropical forests. Ecology 76:2544-2561. 
HARTSHORN, G. 1983. Plants - introduction. Pp. 118-157 in Janzen, D. A. (ed.). Costa Rican natural history. University of Chicago Press, Chicago.

HEANY, A. \& PROCTOR, J. 1990. Preliminary studies on forest structure and floristics on Volcan Barva, Costa Rica. Journal of Tropical Ecology 6:307-320.

HUBER, O. 1995. Vegetation. Pp. 97-160 in Berry, P. E., Holst, B. K. \& Yatskievych, K. (eds). Flora of Venezualan Guayana. Volume 1. Introduction. Missouri Botanical Garden, St. Louis.

HUSTON, M. A. 1980. Soil nutrients and tree species richness in Costa Rican forests. Journal of Biogeography 7:147-157.

HUSTON, M. A. 1994. Biological diversity. The coexistence of species on changing landscapes. Cambridge University Press, Cambridge, UK. 681 pp.

IGAC, Instituto Geografico Augustin Codazzi 1993. Aspectos ambientales para el ordenamiento territorial del occidente del departamento del Caquetá. Tropenbos Colombia, Bogotá, Colombia. 1641 pp.

JOHNSTON, M. \& GILLMAN, M. 1995. Tree population studies in low-diversity forests, Guyana. I. Floristic composition and stand structure. Biodiversity and Conservation 4:339-362.

JONKERS, W. B. J. 1987. Vegetation structure logging damage and silviculture in a tropical rain forest in Suriname. Wageningen Agricultural University, Wageningen, The Netherlands. 172 pp.

KAHN, F. \& DE GRANVILle, J.-J. 1992. Palms in forest ecosystems of Amazonia. Ecological Studies 95. Springer Verlag, Berlin. 226 pp.

KAY, R. F., MADDEN, R. H., VAN SCHAIK, G. \& HIGDON, D. 1997. Primate species richness is determined by plant productivity: implications for conservation. Proceedings of the National Academy of Sciences USA. 94:13023-13027.

KORNING, J. \& BALSLEV, H. 1994. Growth and mortality of trees in Amazonian tropical rain forest in Ecuador. Journal of Vegetation Science 4:77-86.

LAURANCE, W. F., FERREIRA, L. V., RANKIN-DE MERONA, J. M. \& HUTCHINGS, R. W. 1998. Influence of plot shape on estimates of tree diversity and community composition in central Amazonia. Biotropica 30:662-665.

LEIGH, E. G. 1995 Epilogue: Research on Barro Colorado Island 1980-1994. Pp. 496-503 in Leigh E. G., Rand, A. S \& Windsor D. M. (eds). The ecology of a tropical rain forest, seasonal rhythms and long term changes. Smithsonian Institution Press, Washington.

LIZARRALDE, M. 1997. Perception, knowledge and use of the rain forest: ethnobotany of the Bari of Venezuela. PhD Thesis, University of California.

LLERAS, E. 1997. Upper Rio Negro region. Brazil, Colombia, Venezuela. Pp. 333-337 in Davis, S. D., Heywood, V. H., Herrera-MacBryde, O., Vila-Lobos, J. \& Hamilton, A. C. (eds). Centres of plant diversity. A guide and strategy for their conservation. Volume 3. The Americas. World-Wide Fund for Nature \& World Conservation Union, Gland.

LONDOÑA VEGA, A. C. 1993. Análisis estructural de dos bosques asociados a unidades fisiographicas contrastantes, en la región de Araracuara (Amazonia Colombiana). Universidad de Colombia, Medellín, Colombia.

MAAS, P. J. M. 1971. Floristic observations on forest types in western Suriname I and II. Proceedings of the Koninklijke Nederlandse Academie van Wetenschappen Ser. C 74:269-302.

MAAS, P. J. M. \& WESTRA, L. Y. Th. 1993. Neotropical plant families. Koeltz Scientific Books, Koenigstein, Germany. 290 pp.

MACIEL, U. N. \& LISBOA, P. L. B. 1989. Estudo florístico de 1 hectarea de mata de terra firme Km 15 da rodovia Presidente Médici-Costa Marques (RO-429), Rondônia. Boletim do Museu Paraense Emílio Goeldi. Serie Botânica 5:25-37.

MARIN, E. \& CHAVIEL, A. 1996. La vegetación: bosques de tierra firme. Pp. 60-65 in Rosales, J. \& Huber O. (eds). Ecología de la Guenca del Río Cauca, Venezuela I. Caracterización general. Scientia Guaianae 6.

MARZLUFF, J. M. \& DIAL K. P. 1991. Life history correlates of taxonomic diversity. Ecology 72:428439.

MILLIKEN, W. 1998. Structure and composition of one hectare of central Amazonian terra firme forest. Biotropica 30:530-537.

MILLIKEN, W. \& RATTER, J. A. 1998. The vegetation of the Ilha de Maraca. Pp. 71-112 in Milliken W. \& Ratter J. A. (eds). Maraca: the biodiversity and environment of an Amazonian rain forest. John Wiley \& Sons, New York.

MORI, S. A. \& BOOM, B. M. 1987. The forest. Memoirs of the New York Botanical Garden 44:9-29.

MORI, S. A., BOOM, B. M., CARVAlHO, A. M. \& DOS SANTOS, T. S. 1983. Southern Bahian moist forests. Botanical Review 149:155-232.

MORI, S. A., BECKER, P. \& KINCAID, D. In press. Lecythidaceae of a central Amazonian lowland forest: implications for conservation. In Bierregaard R. (ed.). Lessons from Amazonia. Yale University Press, New Haven, USA.

MORI, S. A., RABELO, B. V., TSOU, C.-H. \& DALY, D. 1989. Composition and structure of an eastern Amazonian forest at Camaipa, Amapá, Brazil. Boletim do Museu Paraense Emílio Goeldi. Serie Botanica. Serie Botânica 5:3-18. 
NELSON, B. W., FERREIRA, G. A. G., DA SILVA, M. F. \& KAWASAKI, M. L. 1990. Endemism centres, refugia and botanical collection density in Brazilian Amazonia. Nature 345:714-716.

OLIVEIRA, A. A. de 1997. Diversidade, estrutura e dinâmica do componente arbóreo de uma floresta de terra firme de Manaus, Amazonas. Ph. D. dissertation, Instituto de Biociências da Universidade de São Paulo.

OLIVEIRA, A. A. DE \& MORI, S. A. 1999. A central Amazonian terra firme forest I. High tree species richness on poor soils. Biodiversity and Conservation 8:1219-1244.

PANNATIER, Y. 1996. VARIOWIN: software for spatial data analysis in 2D. Springer-Verlag, New York, USA. 91 pp.

PERES, C. A. 1994. Primate response to phenological changes in an Amazonian terra firme forest. Biotropica 26:98-112.

PHILliPS, O. L., HALL, P., GENTRY, A. H., SAWYER, A. S. \& VASQUEZ, R. 1994. Dynamics and species richness of tropical rain forests. Proceedings of the National Academy of Sciences, USA 91:28052809.

PIRES, J. M. 1997. Transverse dry belt of Brazil. Pp. 319-324 in Davis, S. D., Heywood, V. H., Herrera-MacBryde, O., Vila-Lobos, J. \& Hamilton, A. C. (eds). Centres of plant diversity. A guide and strategy for their conservation. Volume 3. The Americas. World-Wide Fund for Nature \& World Conservation Union, Gland.

PIRES, J. M., DOBZHANSKY, T. H. \& BLACK, G. A. 1953. An estimate of the number of species of trees in an Amazonian forest community. Botanical Gazette 114:467-477.

PIRES, J. M. \& KOURY, H. M. 1958. Estudo de um trecho de mata várzea próximo Belém. Boletim Téchnico I. A. N. 36:3-44.

PIRES, J. M. \& PRANCE, G. T. 1984. The vegetation types of the Brazilian Amazon. Pp. 109-145 in Prance, G. T. \& Lovejoy, T. E. (eds). Amazonia. Pergamon Press, Oxford.

PITMAN, N. G. A., TERBORGH, J., SILMAN, M. R. \& NUNEZ-V, P. 1999. Tree species distributions in an upper Amazonian forest. Ecology 80:2651-2661.

PRANCE, G. T. 1982. Forest refuges: evidence from woody angiosperms. Pp. 137-138 in Prance, G. T. (ed.). Biological diversification in the tropics. Columbia University Press, New York.

PRANCE, G. T. 1986. Chrysobalanaceae. Flora of the Guianas, Series A, fascicle 2. Koeltz Scientific Books, Koenigstein, Germany. 148 pp.

PRANCE, G. T. 1987. Vegetation. Pp. 28-45 in Whitmore T. C. \& Prance, G. T. (eds). Biogeography and quaternary history in tropical America. Clarendon Press, Oxford.

PRANCE, G. T. 1990. Floristic composition of the forests of central Amazonian Brazil. Pp. 112-140 in Gentry, A. H. (ed.). Four neotropical rain forests. Yale University Press, New Haven.

RAich, J. W., RASTetTer, E. B., Melillo, J. M., KiCKlighter, D. W., Steudler, P. A., PETERSON, B. J., GRACE, A. L., MOORE III, B. \& VÖRÖSMARTY, C. J. 1991. Potential net primary productivity in South America: application of a global model. Ecological Applications 1:399429.

RAMDASS, I., SINGH, J., TAMESSAR, M. \& GOPAUL, D. 1997. National activity on the use of biodiversity, Guyana. UNDP/Office of the President/University of Guyana, Georgetown, Guyana.

RADAMBRASIL. 1968-1978. Levantamento de Recursos Naturais. Vols 1-18. Ministério de Minas e Energia. Departamento Nacional de Produção Mineral, Rio de Janeiro.

RANKIN-DE MERONA, J. M., HUTCHINGS, R. W. \& LOVEJOY, T. E. 1990. Tree mortality and recruitment over a five-year period in undisturbed upland rain forest of the central Amazon. Pp. 573-584 in Gentry, A. H. (ed.). Four neotropical rain forests. Yale University Press, New Haven.

RANKIN-DE MERONA, J. M., PRANCE, G. T., HUTCHINGS, R. W., DA SILVA, M. F., RODRIGUES, W. A. \& UEHLING, M. E. 1992. Preliminary results of a large-scale tree inventory of upland rain forest in the Central Amazon Acta Amazônica 22:493-534.

RICHTER, D. D. \& BABBAR, L. I. 1991. Soil diversity in the tropics. Advances in Ecological Research 21:315-389.

RODRIGUES, W. A. 1963. Estudo de 2,6 hectareas de mata terra firme da Serra do Navio, Território do Amapá. Boletim do Museu Paraense Emílio Goeldi Nova Série 19.

ROHDE, K. 1992. Latitudinal gradients in species diversity: the search for the primary cause. Oikos 65:514-527.

ROLLET, B. 1993. Tree populations in natural rain forests. A case study: Brazilian Amazonia. Bois et Forêts des Tropiques 236:43-55.

ROSALES-GODOY, J., PETTS, G. \& SALO, J. 1999. Riparian flooded forests of the Orinoco and Amazon basins: a comparative review. Biodiversity and Conservation 8:551-586.

ROSEnZWEIG, M. L. 1995. Species diversity in space and time. Cambridge University Press, Cambridge, UK. 436.

SABATIER, D. 1990. Diversité des arbres et du peuplement forestier en Guyane. Pp. 41-47 in Gestion de l'écosystème forestier et aménagement de l'espace régional. SEPANGUI Cayenne. pp. 
SABATIER, D. \& PREVOST, M. F. 1987. Une forêt a Cacaoyers sauvages sure le Haut-Camopi, en Guyane Française. ORSTOM, Cayenne, France. 29 pp.

SABAtier, D., GRimaldi, M., PREvOSt, M.-F., GUIllaume, J., GODRON, M., DOSSO, M. \& CURMI, P. 1997. The influence of soil cover organization on the floristic and structural heterogeneity of a Guianan rain forest. Plant Ecology 131:81-108.

SAlO, J., KALliOlA, R., HÄKKINEN, I., MÄKINEN, Y., NIEMELÄ, P., PUHAKKA, M. \& COLEY, P. D. 1986. River dynamics and the diversity of Amazon lowland rain forest. Nature 322:254-258.

SALOMÃO, R. P. 1991. Uso de parceles permanentes para estudos da vegetação da floresta tropical úmida. I. Município de Marabá, Pará. Boletim do Museu Paraense Emílio Goeldi. Serie Botânica 7:543604.

SALOMÃO, R. P. \& LISBOA, P. L. 1988. Análise ecológica da vegetação de uma floresta pluvial tropical de terra firme, Rondônia. Boletim do Museu Paraense Emílio Goeldi. Serie Botânica 4:195-233.

SALOMÃO, R. P., SILVA, M. F. F. \& LISBOA, P. L. 1988. Inventario ecológico em floresta pluvial tropical de terra firme, Serra Norte, Carajás, Pará. Boletim do Museu Paraense Emílio Goeldi Serie Botânica 4:1-46.

SCHULZ, J. P. 1960. Ecological studies on rain forest in northern Surinam. Van Eedenfonds, Amsterdam, The Netherlands.

SILVA, A. S. L., LISBOA, P. L. B. \& MACIEL, U. N. 1992. Diversidade florística e estrutura em floresta densa da bacia do Rio Juruá-Am. Boletim do Museu Paraense Emílio Goeldi Serie Botânica 8:203-253.

SILVA, M. F. F. \& ROSA, N. A. 1989. Análise do estrato arbóreo da vegetação sobre jazidas de cobre na Serra do Carajás-PA. Boletim do Museu Paraense Emílio Goeldi. Serie Botânica 5:175-206.

SILVA, M. F. F., ROSA, N. A. \& OLIVEIRA, J. 1987. Estudos botânicos na área do projecto Ferro Carajás. 5. Aspectos florísticos da mata do Rio Gelado, Pará. Boletim do Museu Paraense Emílio Goeldi. Serie Botânica 3:1-20.

SILVA, M. F. F., ROSA, N. A. \& SALOMÃO, R. P. 1986. Estudos botânicos na área do projecto Ferro Carajás. 3. Aspectos florísticos da mata do aeroporto de Serra Norte - PA. Boletim do Museu Paraense Emílio Goeldi. Serie Botânica 2:169-187.

SMITH, D. N. \& KILLEEN, T. J. 1998. A comparison of the structure and composition of montane and lowland tropical forest in the Serrania Pilón, Beni, Bolivia. Pp. 681-700 in Dallmeier, F. \& Comiskey, J. A. (eds). Forest biodiversity in North, Central and South America, and the Caribbean. Research and monitoring. MAB Series Vol. 21. UNESCO, Paris.

SPICHIGER, R., LOIZEAU, P.-A., LATOUR, C. \& BARRIERA, G. 1996. Tree species richness of a South-Western Amazonian forest (Jenaro Herrera, Peru, 73 40’W/ 4 54'S). Candollea 51:559-577.

STERGIOS, B., COMISKEY, J. A., DALlmEIER, F. \& LICATA A NINO, M. 1998. Species diversity, spatial distribution and structural aspects of semi-deciduous lowland gallery forests in the western Llanos of Venezuela. Pp. 449-479 in Dallmeier, F. \& Comiskey, J. A. (eds). Forest biodiversity in North, Central and South America, and the Caribbean. Research and monitoring. MAB Series Vol. 21. UNESCO, Paris.

STERN, M. J. 1998. Field comparisons of two rapid vegetation assessment techniques with permanent plot inventory data in Amazonian Peru. Pp. 269-283 in Dallmeier, F. \& Comiskey, J. A. (eds). Forest biodiversity research, monitoring and modelling. Conceptual background and Old World case studies. MAB Series Vol. 20. UNESCO, Paris.

SUDAM. 1974. Levantamentos florestais realizados pela missão FAO na Amazônia. Belém, Vol 2.

TAYLOR, L. R., KEMPTON, R. A. \& WOIWOD, I. P. 1976. Diversity statistics and the log-series model. Journal of Animal Ecology 45:255-272.

TER STEEGE, H. 1998a. The use of forest inventory data for a National Protected Area Strategy in Guyana. Biodiversity and Conservation 7:1457-1483.

TER STEEGE, H. 1998b. Biomass estimates for forest in Guyana and their use in carbon offsets. Iwokrama International Centre for Rain Forest Conservation and Development/UNDP, Georgetown, Guyana. $50 \mathrm{pp}$.

TER STEEGE, H., JANSEN-JAGOBS M. J. \& DATADIN, V. (2000). Can botanical collections assist in a National Protected Area Strategy in Guyana? Biodiversity and Conservation 9:215-240.

TER STEEGE, H., JETTEN, V. G., POLAK, M. \& WERGER, M. J. A. 1993. The tropical rain forest types and soils of a watershed in Guyana, South America. Journal of Vegetation Science 4:705-716.

TERBORGH, J. 1973. On the notion of favorableness in plant ecology. American Naturalist 107:481-501.

TERBORGH, J. \& ANDRESEN, E. 1998. The composition of Amazonian forests: patterns at local and regional scale. Journal of Tropical Ecology 14:645-664.

TOMLINSON, P. B. 1986. The botany of mangroves. Cambridge University Press, Cambridge, UK. 413 pp.

TUOMISTO, H. \& RUOKOLAINEN, K. 1997. The role of ecological knowledge in explaining biogeography and biodiversity in Amazonia. Biodiversity and Conservation 6:347-357.

TUOMisto, H., RUOKOlAinen, K., KAlliOlA, R., LINNA, A., DANJOY, W. \& RODRIGUEZ, Z. 1995. Dissecting Amazonian biodiversity. Science 269:63-66. 
UHL, G. \& MURPHY, P. G. 1981. Composition, structure, and regeneration of terra firme forest in the Amazon basin of Venezuela. Tropical Biology 22:219-237.

URREGO GIRRALDO, L. E. 1997. Los bosques inundables del Medio Caqueta. Caracterización y sucesión Estudios en la Amazonia Colombiana XIV. Tropenbos Colombia, Bogota.

VALENGIA, R., BALSEV, H., PALACIOS, W., NEILl, D., JOSSE, C., TIRADO, M. \& SKOV, F. 1998. Diversity and family composition of trees in different regions of Ecuador: a sample of 18 one-hectare plots. Pp. 569-584 in Dallmeier, F. \& Comiskey, J. A. (eds). Forest biodiversity in North, Central and South America, and the Caribbean. Research and monitoring. MAB Series Vol. 21. UNESCO, Paris, France.

VALENCIA, R., BALSLEV, H. \& PAZ Y MINO, G. 1994. High tree alpha-diversity in Amazonian Ecuador. Biodiversity and Conservation 3:21-28.

VEGA, L. C. 1968. La estructura y composición de los bosques húmedos tropicales del Carare, Colombia. Turrialba 18:416-436.

VOSS, R. S. \& EMMONS, L. H. 1996. Mammalian diversity in neotropical lowland rain forests: a preliminary assessment. Bulletin of the American Museum of Natural History 230:1-115.

WORBES, M., KLINGE, H., REVILLA, J. D. \& MARTIUS, C. 1992. On the dynamics, floristic subdivision and geographical distribution of várzea forests in Central Amazonia. Journal of Vegetation Science 3:553564.

ZOBEL, M. 1997. The relative role of species pools in determining plant species richness: an alternative explanation of species coexistence? Trends in Ecology and Evolution 12:266-269. 


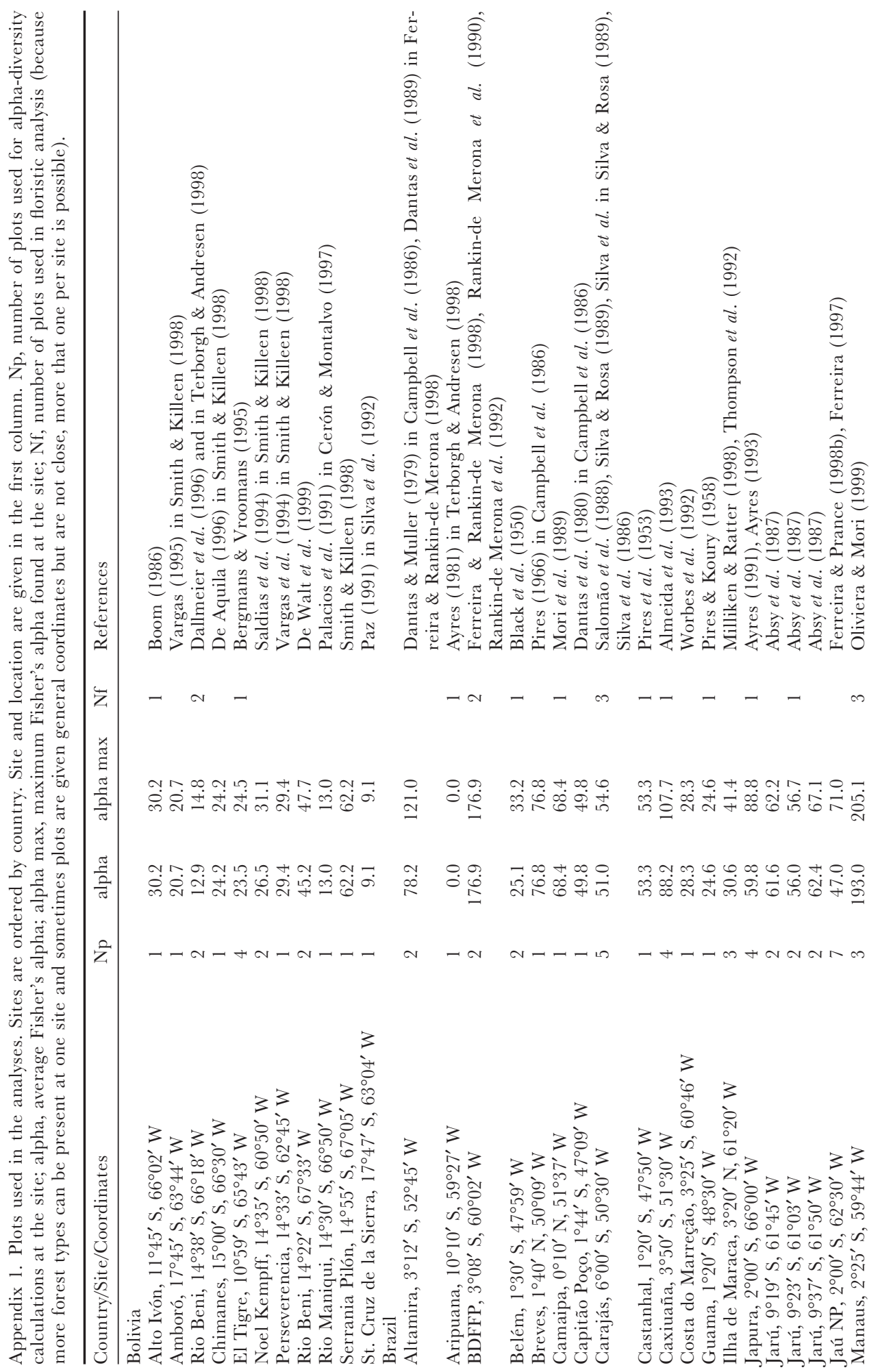




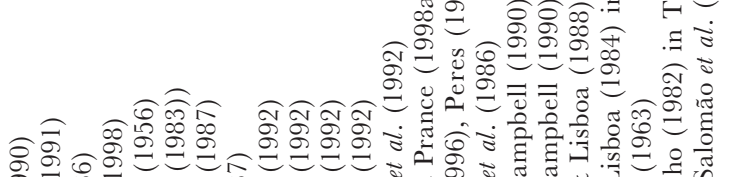
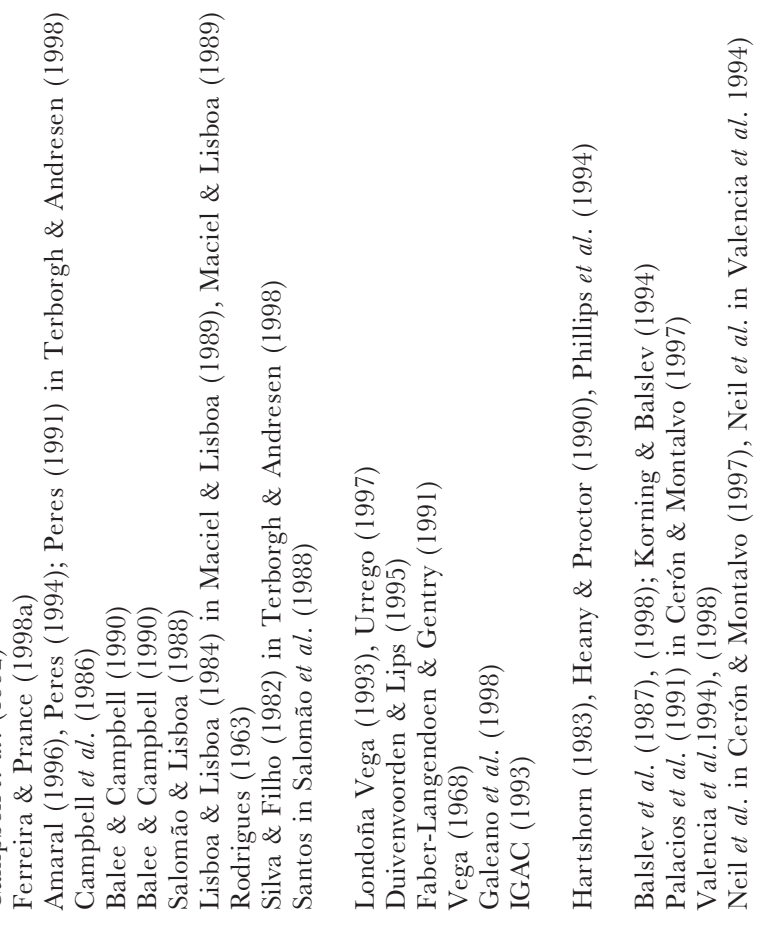

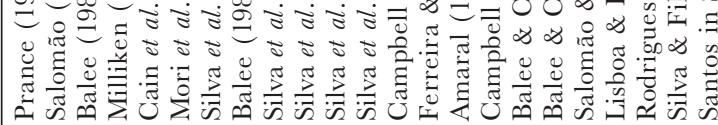

$\ln$ t



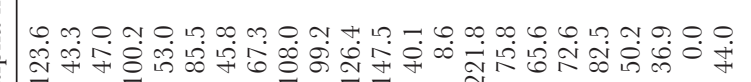

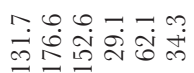



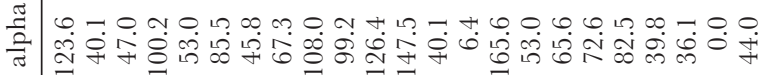

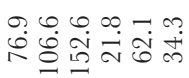

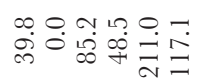

育

$-$

$n \infty \pi-a n m-\infty$

3

3
8
8
8

3

$3=\frac{3}{2}$

$3 \stackrel{3}{3}$

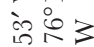

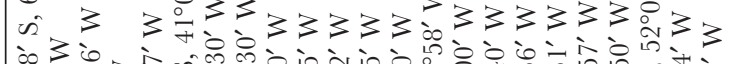

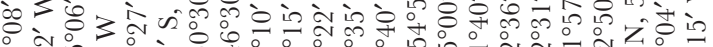

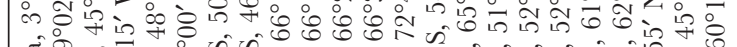

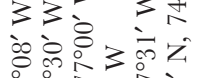

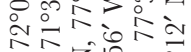

थिच

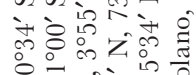

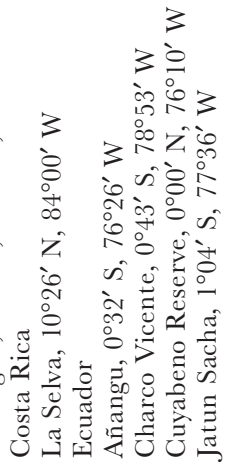




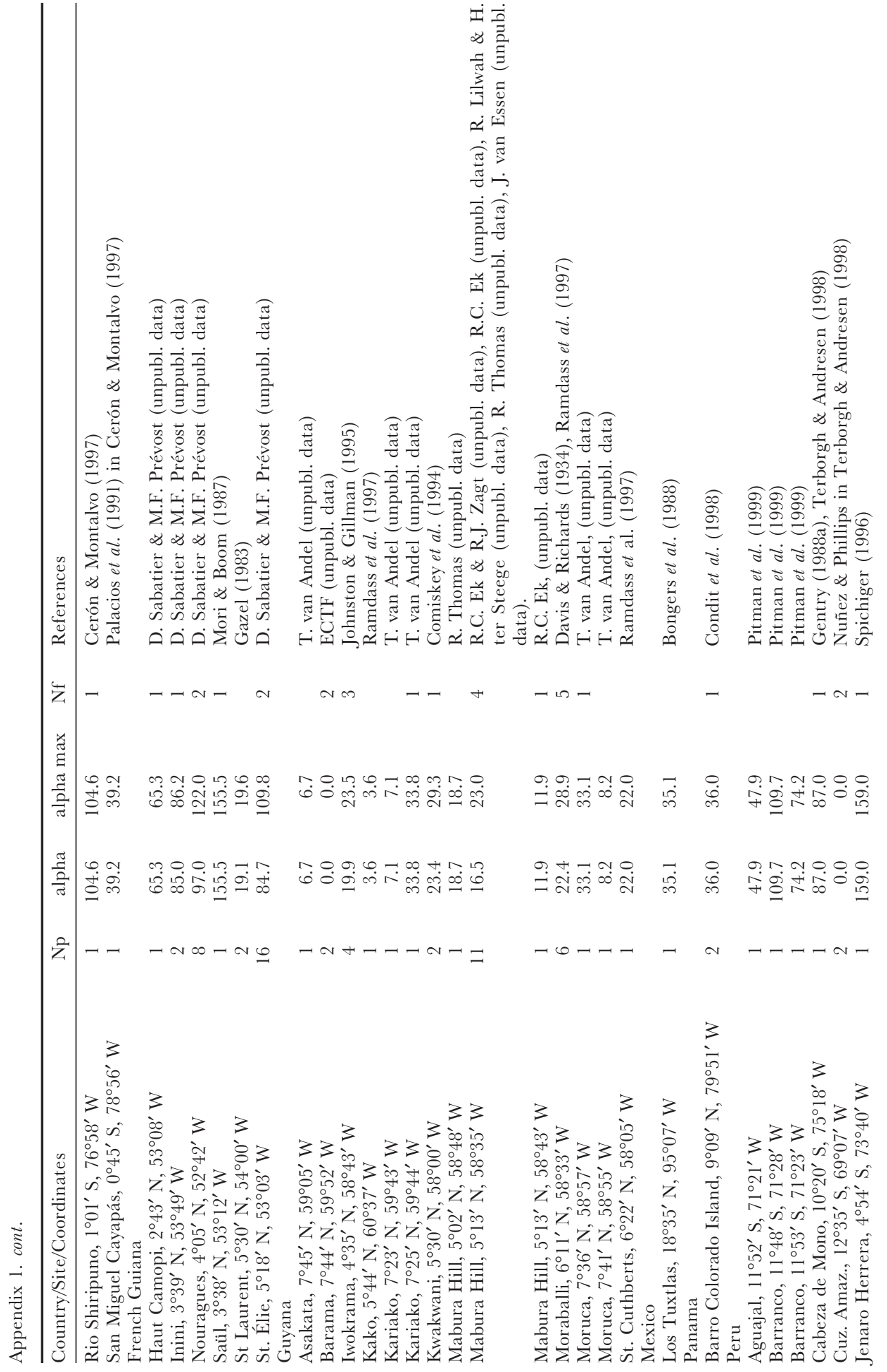




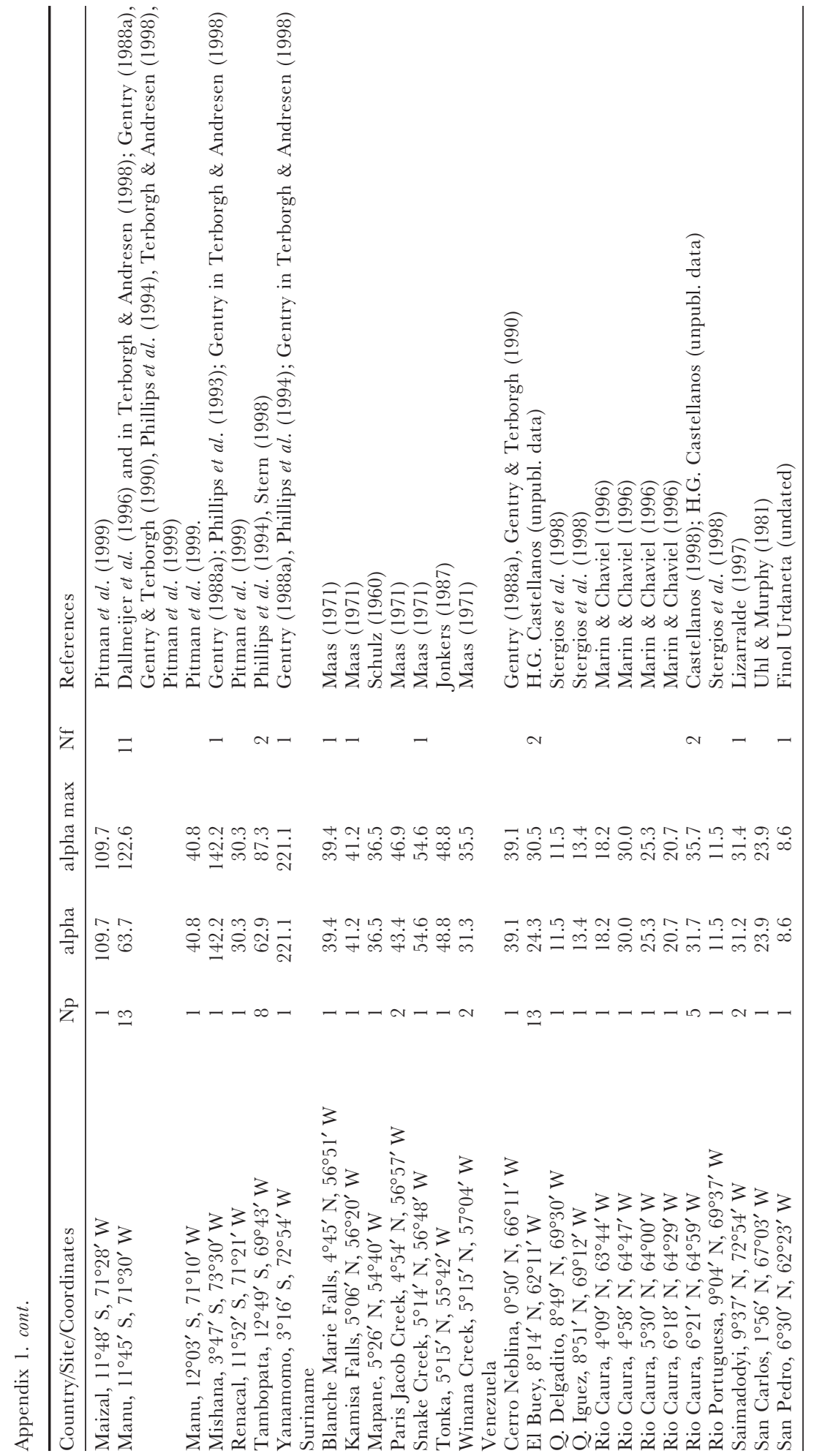

